\title{
Terrorismo, manifestações sociais e democracia: uma análise sobre a proposta de alteração da Lei no 13.260/2016 no Brasil
}

\section{Danielle Maia Cruz* (D) \\ Fábio Carvalho de Alvarenga Peixoto* (1)}

\section{Resumo}

O artigo analisa possibilidades de impactos em manifestações sociais a partir de uma possível alteração da Lei no 13.260/2016 (Lei Antiterrorismo) pelo Projeto de Lei do Senado no 272/2016, que visa a disciplinar, com mais rigor e precisão, condutas tidas como atos de terrorismo. O reavivamento desse debate ocorreu no início de 2019, quando coletivos criminais, conhecidos como "facções", envolvidos com o mercado de drogas no Ceará, promoveram uma série de ações violentas alterando radicalmente o cotidiano das pessoas, levando a população a clamar por atitudes rígidas do Estado contra o que foi intuído como terrorismo. A pesquisa, de natureza qualitativa, aponta as dinâmicas das facções no Ceará e diferenças com relação a outras modalidades de organização social voltadas historicamente à luta por direitos constitucionais, além de demonstrar as dificuldades em tipificar como terroristas atos praticados por coletivos criminais sem, ao mesmo tempo, prover ao Estado meios para também coibir as práticas de movimentos sociais, inclusive por motivações políticas. Conclui-se que os efeitos de possíveis alterações na Lei Antiterrorismo seriam severos para a dinâmica da democracia, ao reprimir possivelmente práticas coletivas historicamente fundamentais para assegurar direitos diversos em uma sociedade plural.

Palavras-chave: Lei Antiterrorismo, facções, manifestações sociais, democracia.

* Universidade de Fortaleza, Fortaleza, Ceará, Brasil. 


\section{Terrorism, social movements and democracy: an analysis on the proposed amendment of Law 13,260 of 2016, in Brazil}

\section{Abstract}

The article analyzes possibilities of impacts on social manifestations to be triggered by a proposed amendment of Law 13,260/2016 (Antiterrorism Law) by Senate Bill $272 / 2016$, which aims to intensify penalties on actions considered as acts of terrorism. The revival of this debate occurred in early 2019, when criminal collectives, known as facções [factions], involved in the drug market in Ceará State, promoted a series of violent actions that radically altered people's daily lives, leading the population to cry out for severe State attitudes against what was perceived as terrorism. The qualitative research points out the dynamics of drug factions in Ceará State and the differences in relation to other modalities of social organization historically focused on the struggle for constitutional rights, as well as demonstrating the difficulties in classifying acts carried out by criminal collectives as terrorists, without simultaneously providing the State with the means to also curb the practices of social movements, including for political reasons. It is concluded that the effects of possible changes in the Antiterrorism Law would be severe for the dynamics of democracy, possibly repressing historically fundamental collective practices to ensure multiple rights in a plural society.

Keywords: Antiterrorism Law, factions, social protests, democracy.

\section{Introdução}

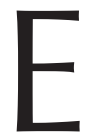

ste artigo analisa as ações praticadas por facções criminosas ${ }^{1}$ envolvidas com o mercado ilegal de drogas no estado do Ceará nos primeiros dias de 2019 e sua relação com o reavivamento da discussão sobre a tipificação de tais atos como terroristas, a partir de uma possível alteração da Lei no 13.260/2016 (Lei Antiterrorismo) pelo Projeto de Lei do

\footnotetext{
${ }^{1}$ Conforme explicita Paiva (2019, p. 167), ainda que facção seja o termo mais recorrente para designar tais coletivos, outras nomenclaturas "[...] são também usuais, tais como 'crime organizado', 'o comando', 'o bonde', 'o trem', 'a tropa', 'a família', 'os irmãos', entre outras maneiras de falar do grupo." Os termos variam de acordo com os modos como os grupos se organizam e se reinventam em torno da prática do crime. No presente artigo, o sentido tomado é o de que tais coletivos se fazem a partir de múltiplas práticas e maneiras de fazer o cotidiano, conforme argumenta Paiva (2019) apoiado em Certeau (1994).
} 
Senado no 272/2016, que visa a "disciplinar com mais precisão condutas consideradas como atos de terrorismo" (Brasil, 2016c). Discutem-se os possíveis impactos dessa alteração sobre as liberdades constitucionais asseguradas aos movimentos sociais, coletivos e demais organizações da sociedade civil, bem como manifestações públicas, na luta em prol da garantia de direitos.

A Lei no 13.260/2016, que tipificou os crimes de terrorismo e de organização terrorista, foi sancionada no Governo Dilma Rousseff, em decorrência, segundo Forte (2016), das exigências internacionais e nacionais de um instrumento legal apto a conter ações consideradas violentas de alguns grupos, que colocariam em risco a segurança de atletas e espectadores de distintas nacionalidades presentes nos Jogos Olímpicos, realizados em 2016, no Brasil. Registrem-se como antecedentes as Jornadas de Junho de 2013 e as intensas manifestações de protesto ocorridas antes e durante a Copa das Confederações de 2013 e a Copa do Mundo de 2014, quando o país se viu diante de intensos cenários de protestos contra o governo, reforçados em março de 2015, quando milhares de pessoas foram às ruas com novas demandas. Por conta das situações de violência promovidas por alguns grupos, gerou-se uma sensação de pânico e insegurança no país, especialmente relacionada à realização do evento olímpico.

Assim, em 2016, foi sancionada a Lei no 13.260/2016, ou Lei Antiterrorismo, sendo o texto aprovado no Congresso Nacional objeto de vetos presidenciais a oito dispositivos, dentre os quais o dispositivo que qualificava como terroristas as ações de "incendiar, depredar, saquear, destruir ou explodir meios de transporte ou qualquer bem público ou privado" (Brasil, 2016a). O que norteou os vetos não foi propriamente questões relacionadas à segurança contra o terrorismo, e sim a preocupação com os efeitos reflexos da lei sobre as liberdades de reunião e manifestação, em geral, e sobre os movimentos sociais, especificamente.

Já à época dos debates parlamentares, ocorridos em 2015 e 2016, a Organização das Nações Unidas (ONU) chegou a alertar que a lei poderia silenciar defensores de direitos humanos, coletivos, movimentos de massa, 
manifestações sociais, dentre outras formas de organização em prol de direitos constitucionalmente garantidos (Nações Unidas, 2015). Isso trouxe forte mobilização contra o texto original, organizada, por exemplo, pelo Greenpeace e diversas ONGs, pelo Movimento dos Trabalhadores Sem Teto (MTST) e pelo Movimento dos Trabalhadores Rurais Sem Terra (MST), por entenderem que ele criminalizaria os movimentos sociais (Sousa; Gorczevski, 2018).

Contudo, logo após a sanção presidencial e consequente publicação da Lei no 13.260/2016, ainda argumentando sobre o cenário de insegurança no país, foi apresentado pelo Senador Laisier Martins (PDT/RS) o Projeto de Lei do Senado no 272/2016, visando a modificá-la, sob a justificativa de que "a então presidente mutilou a Lei Antiterrorismo e, assim, tornou-a, em aspectos fundamentais, inócua" (Brasil, 2016c). Em 2019, no contexto de ataques de facções criminosas a equipamentos e espaços públicos e privados, em diferentes localidades do estado do Ceará, as discussões sobre o projeto modificativo da Lei no 13.260/2016 foram impulsionadas pelo amplo clamor popular em busca de uma intervenção estatal mais contundente contra as ações das facções - intuídas amplamente, nos discursos da sociedade, como "ameaças terroristas". ${ }^{2}$ A ideia foi também reforçada, à época, por autoridades públicas, como o presidente da República Jair Bolsonaro.

Em razão dos atos violentos, o estado do Ceará foi propalado, nos discursos do senso comum, da mídia e de autoridades públicas, como cenário de terror e guerra. As metáforas utilizadas naquele momento são uma chave fundamental para se pensar os significados, no estado do Ceará, de redes complexas organizadas em torno do tráfico de drogas.

Portanto a problemática do artigo gravita em torno do fenômeno da possível alteração da Lei no 13.260/2016 pelo Projeto de Lei do Senado no 272/2016, notadamente de seus prováveis reflexos na garantia do exercício

${ }^{2}$ A noção de "ameaça terrorista" é vaga e tem nítido foro íntimo. Assim, o que é percebido em algumas culturas como um elemento ameaçador não o é em outras. Por exemplo, o estereótipo de um homem muçulmano é percebido em algumas comunidades dos Estados Unidos como uma severa ameaça; enquanto, em outros lugares, imersos em culturas não forjadas por preconceitos, é percebido de forma nada ameaçadora. Por isso, diz-se que a ameaça é intuída, opondo-se, assim, a uma racionalização. 
de liberdades constitucionais asseguradas aos movimentos sociais e aos seus integrantes. Posto isso, o argumento central é que a alteração da Lei no 13.260/2016, nos termos propostos, atentará severamente contra as bases do Estado democrático de direito. Observa-se que a tipificação proposta pode culminar na criminalização, como terroristas, de atos praticados em manifestações, por movimentos sociais e coletivos que, a partir de estratégias múltiplas, pronunciam-se historicamente no país, nas esferas públicas, na tentativa de pressionar o Estado a efetivar direitos básicos, como cultura, saúde, educação e a própria segurança pública.

Para melhor compreensão, na primeira seção do artigo, discutem-se as questões normativas referentes à tipificação do terrorismo como crime, inclusive no Brasil. Em seguida, analisam-se as práticas de facções no estado do Ceará, coletivos envolvidos com o mercado ilegal de drogas, apontando suas maneiras de organização em torno do crime. Posteriormente, discutemse as diferenças entre os coletivos criminais e as práticas de sujeitos coletivos que, mobilizados por questões subjetivas diversas, lançam-se às ruas ou se articulam em redes sociais pela garantia de direitos constitucionais, inclusive segurança pública. Por fim, apontam-se os possíveis efeitos da alteração da Lei no 13.260/2016 na organização dos movimentos sociais, e, nesse sentido, as fissuras que provocaria na noção de democracia.

A pesquisa adotou uma abordagem qualitativa, fundamentada em fontes bibliográficas e documentais, e seguiu duas linhas principais: juridicamente, analisou-se a definição do crime de terrorismo - cujo repúdio se encontra na Constituição brasileira, porém sem refinamento - estabelecida pela Lei no 13.260/2016; sociologicamente, o estudo buscou apontar questões mais estruturais em torno da dinâmica dos movimentos sociais, considerando que tais mobilizações ocorrem a partir de processos de subjetivação diversos que mobilizam os sujeitos em torno de uma ação. Além disso, problematizou a noção de democracia a partir de questões epistemológicas no cerne das discussões sobre o tema: consenso e conflito, considerando a importância deste último, especialmente em sociedades fortemente marcadas por desigualdades de cor, classe, gênero e geração, como o Brasil. 


\section{O terrorismo como ação típica}

Os atentados de 11 de setembro de 2001 são certamente inesquecíveis: aviões colidindo com prédios símbolos da cidade de Nova lorque, pessoas se jogando pelos ares, barulhos de sirenes, pontes fechadas por toda a cidade e o odor de carne queimada durante semanas marcaram a memória de milhares de pessoas, bem como renderam, em diversas partes do mundo, publicações, produções cinematográficas, rodas de debates e manifestações coletivas de consternação. A forma como aqueles fatos foram midiatizados configura o que Coelho (2004, p. 125) denominou de um "imaginário do cinema hollywoodiano".

Desde aquele episódio, o terrorismo se tornou assunto central da política externa estadunidense. O então presidente George W. Bush definiu-se como aquele cuja missão era extirpar do planeta os atos terroristas. Diversas foram as estratégias adotadas, dentre outras: invasão a "países suspeitos", técnicas de espionagem, rompimento de relações diplomáticas, prisões com e sem determinação judicial, publicidade massiva contra o inimigo comum e reforço em ações para o fechamento das fronteiras.

O terrorismo, no entanto, não foi exterminado. Episódios como o assassinato pelo Estado Islâmico de 1.700 cadetes iraquianos em 2014 (Alkhudary, 2019); os ataques do Boko Haram aos moradores das cidades de Maiduguri em 2009, que vitimaram duas mil pessoas (Massacre..., 2015), e de Baga (Fessy, 2015) e Doro Gowon (Nossiter, 2015) em 2015; o massacre dos jornalistas do Charlie Hebdo (Petrikowski, 2019) e dos frequentadores da boate Bataclan (Hartmann, 2015), em Paris, também em 2015; os atropelamentos ocorridos em Nice no ano seguinte (Chrisafis; Fischer; Rice-Oxley, 2016) são apenas alguns lembretes desse tipo de ação que assola pessoas em distintas partes do planeta.

De acordo com Pape (2003), o terrorismo é um ato que se centra no uso da violência por grupos criminosos voltados expressamente a causar intimidação, medo e sofrimento em pessoas de uma dada sociedade. Não se trata, argumenta o autor, de atividades dos governos nacionais contra grupos específicos, tidos como inimigos-alvo - o que se pode definir como 
"terror", em oposição a "terrorismo" (Soares, 2003). Para ele, a lógica de conformação dos grupos terroristas tem especificidades nas ações, nos recursos simbólicos e econômicos, e nas motivações: o grupo terrorista produz conflitos visando a angariar apoio para sua causa (em âmbito local ou internacional) por meio da imposição da violência à população.

Pape (2003) destaca a existência de tipos de terrorismo. Há, por exemplo, o terrorismo com fins de recrutamento de pessoas para sua causa, geralmente precedido de anúncios públicos, e ainda aqueles movidos por altas doses de terror, como as ações das Forças Armadas Revolucionárias da Colômbia. Destaca, igualmente, o terrorismo com foco no ataque suicida, geralmente realizado por homem-bomba. Sobre essas considerações, já se destacou que "o recurso ao fanatismo religioso não é suficiente para explicar as causas do terrorismo suicida" (Costa, 2006, p. 4).

As observações de Pape (2003) e de Costa (2006) denotam que inexiste uma causa única para o terrorismo. Há, portanto, que se ter o cuidado de analisar o fenômeno de uma forma geral, e não por meio de uma abordagem fixada no terrorismo jihadista, muito em evidência nos últimos tempos. Soares (2003, p. 1-2), muito embora escrevendo ainda no rescaldo dos eventos de setembro de 2001, tem uma percepção mais geral, ao destacar que, por carregar consigo "um grande componente de ordem moral", a tarefa de definir o terrorismo mostrou-se, na prática, inexequível; isso porque as definições até hoje propostas não têm aptidão para abranger uma moral universal.

Em reforço ao seu argumento de dificuldade de estabelecimento de um conceito universal de terrorismo, a autora apresenta uma interessante coletânea de pontos de vista sobre o terrorismo - do Departamento Federal de Investigação estadunidense ( $\mathrm{FBI}$ ) a um terrorista palestino - para, ao final, concluir que "a maioria tem elementos em comum, tais como o emprego da violência e o fim político" (Soares, 2003, p. 5). Há autores, como Seixas (2008, p. 22-23), que chegam mesmo a negar a neutralidade científica e a possibilidade "de uma definição consensual de terrorismo", chamando ainda a atenção para a importância de que não se venha a vergar a uma "leitura monolítica do terrorismo", carregada de preconceitos e elementos políticos. 
Sobre a tipificação de uma conduta como terrorista, Hobsbawm (2007) traz algumas problematizações ao tratar da legitimidade em torno dos modelos de Estado democrático de direito no século XXI, amplamente difundidos nos países de tradição liberal. Ao discorrer com ceticismo sobre as perspectivas democráticas no milênio, o autor afirma que elas estão em processo de esfacelamento, dado o enfraquecimento do Estado. O historiador registra o crescimento de atos violentos desde os anos 1960, especialmente movidos por grupos massivamente armados, ansiosos para derrubar os regimes vigentes na Europa Ocidental ou movidos por ideias separatistas. Frisa, ainda, a emergência do homem-bomba com base em dogmas religiosos ou questões étnicas, bem como ações violentas articuladas por grupos intelectualizados nos anos 2000.

O argumento central de Hobsbawm (2007) é de que o maior perigo não é o ato terrorista em si, mas os efeitos provocados pela mídia nas representações coletivas, movidos pelos interesses de Estados imperialistas, como os Estados Unidos. Segundo o autor, a indústria do medo é amplamente explorada, autorizando uma dada sociedade a proclamar a guerra contra o terror. Na mesma linha de raciocínio, Krygier (2007, p. 19, tradução nossa) apresenta uma interessante questão: "Terrorismo', como o nome indica, semeia medo. Mas medo do quê, precisamente?"; em resposta, observa que muitas pessoas manifestam um medo tão intenso de serem mortas, que sugerem que devem ser toleradas restrições mais amplas aos seus direitos, como forma de prover os "combatentes contra o terror" dos meios necessários para o combate.

Sugere-se, portanto, um problema fundamental: em nome do combate a que espécies de "ameaças terroristas" se deve autorizar intervenções estatais sobre os direitos das pessoas? Isto é: o que é o terrorismo, a cuja ameaça se responde com a demanda por mais segurança, aumentando o nível de tolerância a ações estatais que, em regra, em uma sociedade democrática, não seriam aceitas?

A ideia de terrorismo é muito antiga. No âmbito jurídico, Prado e Carvalho (2000) observam que o termo surgiu na III Conferência Internacional 
para a Unificação do Direito Penal, ${ }^{3}$ realizada em Bruxelas em 1930. A discussão jurídica intensificou-se logo após os assassinatos, em 1934, do rei iugoslavo Alexandre I e do ministro das Relações Exteriores da França Louis Barthou, por um terrorista macedônio, cujas imagens em filme chocaram todo o mundo (Prado; Carvalho, 2000). A despeito do intenso debate (citem-se, por exemplo, a VI Conferência Internacional de Direito Penal, a Comissão para a Repressão Internacional do Terrorismo, o Convênio de Haia para a repressão do sequestro ilícito de aeronaves, e o Convênio de Montreal para a repressão de atos ilícitos dirigidos contra a segurança da aviação civil), até hoje, no âmbito internacional, inexiste uma definição jurídica precisa de terrorismo.

Por outro lado, um recente levantamento (Avelar, 2018) apontou que "leis antiterrorismo são usadas para reprimir o dissenso em [...] países [...]" como Nicarágua, Egito, Rússia e Turquia. No que se refere à Nicarágua, por exemplo, o Escritório do Alto Comissário das Nações Unidas para os Direitos Humanos qualificou o texto da lei antiterrorista local como "muito vago e [que] permite uma ampla interpretação que poderia provocar a inclusão (na definição de terrorista) de pessoas que estão simplesmente exercendo seu direito de protestar" (ONU..., 2018). De fato, o artigo 4(2) da Lei no 977/2018, da Nicarágua, define atos terroristas como

[...] aqueles que tenham como objetivo causar a morte ou lesões físicas e/ou psíquicas contra qualquer pessoa, quando o propósito do dito ato, por sua natureza e contexto, é intimidar uma população ou obrigar um Governo ou uma organização internacional a realizar um ato ou a abster-se de fazê-lo [...] (Nicarágua, 2018, tradução nossa, grifo nosso).

\footnotetext{
${ }^{3}$ Segundo Munhoz (1953, p. 121-122), "[n]o Congresso Internacional de Direito Penal, que se reuniu em Bruxelas, no ano de 1926, o Prof. Vespasiano V. Pella, tendo em vista a circunstância de estarem, naquela época, em elaboração vários novos Projetos de Código Penal, em diferentes países, e considerando 'como altamente desejável a unificação das ideias fundamentais para o exercício da repressão', propôs que se reunissem em Conferência Internacional as Comissões encarregadas, em cada Estado, da elaboração daqueles Projetos". Em 1927, a reunião ocorreu em Varsóvia; em 1928, em Roma; em 1930, em Bruxelas; em 1931, em Paris; em 1933, em Madri; em 1935, em Copenhague; em 1938, no Cairo; e, em 1947, novamente em Paris.
} 
Esta vagueza a que se referiu a ONU no caso da Nicarágua, segundo Saint-Pierre (2015, p. 12-13, grifo nosso), torna o inimigo difuso e permite aos governos "caracterizar quaisquer manifestações de descontentamento social como atos terroristas e os movimentos sociais que os promovem como grupos terroristas". Lopes e Santos Jr. (2017, p. 605) citam um caso concreto de aplicação de lei antiterrorismo para perseguição de adversários políticos: a condenação, no Chile, de sete indígenas mapuches e de uma ativista dos direitos desse povo por um suposto atentado sem nenhuma vítima. Os autores observam que o Chile foi, depois, condenado pela Corte Interamericana de Direitos Humanos, em razão dessa mesma decisão. Quando se pensa no Brasil, de forma geral, os debates calorosos sobre o crime de terrorismo, e, de forma específica, a proposição do anteprojeto que resultou na Lei $\mathrm{n}$ $\mathrm{13.260/2016}$ ocorreram a reboque de um cenário de manifestações, entre 2013 e 2015, que levaram milhares de pessoas às ruas a demonstrar sua insatisfação relacionada a serviços públicos. Em 2014, a dinâmica dos protestos foi especialmente marcada nas redes sociais, tendo como pauta central a crítica aos gastos públicos exorbitantes com a realização da Copa das Confederações, de 2013 e com a Copa do Mundo, de 2014. Nesse contexto de multidão dos anos 2013 a 2015, coletivos movidos por práticas de violência também ganharam a cena: transportes públicos foram incendiados, prédios, vitrines de bancos e equipamentos públicos foram danificados. Isso acendeu os debates sobre a tipificação do crime de terrorismo no Brasil.

Antes desses episódios, o crime de terrorismo havia recebido pouca atenção do Estado brasileiro, com exceção do período dos "anos de chumbo" da ditadura civil-militar, conhecidos pelas violações sistemáticas dos direitos humanos (Arquidiocese de São Paulo, 2001). Naquele período histórico, o pretenso combate ao terrorismo era, na verdade, apenas uma fachada para ocultar um combate à dissidência política (Arquidiocese de São Paulo, 2001) - tanto que, quando já se admitia que o país poderia caminhar para a redemocratização, a Lei no 6.683/1979 excluiu expressamente indivíduos condenados pela prática de crimes de terrorismo do direito à anistia (art. 
$\left.1^{\circ}, \S 2^{\circ}\right)$ : "Excetuam-se dos benefícios da anistia os que foram condenados pela prática de crimes de terrorismo [...]" (Brasil, 1979).

Afinal, quem eram os terroristas para o Estado que editou a Lei $\mathrm{n}$ 6.683/1979? A então vigente Lei no 6.620/1978 (Brasil, 1978) estabelecia apenas que constituía crime: "devastar, saquear, assaltar, roubar, sequestrar, incendiar, depredar ou praticar atentado pessoal, sabotagem ou terrorismo, com finalidades atentatórias à Segurança Nacional." Contudo, aquela lei não definiu o que era o "terrorismo" constante do tipo. Tampouco o fez a Lei no 7.170/1983, a Lei de Segurança Nacional, que apenas acresceu ao tipo um elemento de subversão:

Art. 20 - Devastar, saquear, extorquir, roubar, sequestrar, manter em cárcere privado, incendiar, depredar, provocar explosão, praticar atentado pessoal ou atos de terrorismo, por inconformismo político ou para obtenção de fundos destinados à manutenção de organizações políticas clandestinas ou subversivas (Brasil, 1983, grifo nosso).

A parte final do dispositivo deixa transparecer que a norma, nunca formalmente revogada, e muito embora de constitucionalidade duvidosa, objetiva combater não o terrorismo - tal como percebido pela sociedade -, mas a contestação armada ao regime ditatorial. A doutrina não tem dúvida de que o legislador se esquivou do dever de definir de forma precisa o que são os denominados "atos de terrorismo" (Prado; Carvalho, 2000).

A constituição brasileira de 1988, por sua vez, repudiou expressamente o terrorismo (art. 4, VIII), considerado crime inafiançável e insuscetível de graça ou anistia, como dispõe o art. 5 XLIII (Brasil, 1988). Porém, persistiu a lacuna apontada acima: o que é terrorismo? A Constituição não o definiu expressamente, ficando essa definição dependente de juízos discricionários - os quais, ante o silêncio normativo, podem ser impregnados de arbitrariedade.

Observada a separação de poderes, caberia ao Estado-legislador, com sua carga elevada de legitimidade advinda da representação, definir o que é o terrorismo, desde que observados os limites impostos pela Constituição 
(interpretada por seu guardião, o Supremo Tribunal Federal). No ano de 2004, o Supremo Tribunal Federal, em uma definição por exclusão, esclareceu que "os atos delituosos de natureza terrorista não se subsumem à noção de criminalidade política" (Brasil, 2004). Ou seja, embora não se defina o conceito de terrorismo, há um limite a partir do qual uma ação deixa de ser considerada política para ser considerada terrorista. Tal entendimento coincide com o da Convenção Interamericana contra o Terrorismo (Brasil, 2005), segundo a qual nenhum dos delitos de terrorismo "será considerado delito político ou delito conexo com um delito político ou um delito inspirado por motivos políticos".

A exclusão dos crimes políticos diminuiu a potencial abrangência do tipo, que, contudo, permaneceu demasiadamente aberto para uma norma punitiva. A Lei no 13.260/2016 procurou solucionar a questão, tipificando o crime de terrorismo como a "prática por um ou mais indivíduos" de certos atos

[...] por razões de xenofobia, discriminação ou preconceito de raça, cor, etnia e religião, quando cometidos com a finalidade de provocar terror social ou generalizado, expondo a perigo pessoa, patrimônio, a paz pública ou a incolumidade pública [art. $2^{\circ}$, caput] (Brasil, 2016a, grifo nosso).

A Lei no 13.260/2016 (embora de forma linguisticamente redundante) restringiu a tipificação aos atos "cometidos com a finalidade de provocar terror social ou generalizado [...]" (Brasil, 2016a). Afinal, se a ação criminal não visa a provocar terror, é um crime que não pode ser qualificado, ao menos materialmente, como terrorismo. A lei estabelece, como atos terroristas, por exemplo, aqueles que fazem uso de armas nucleares (art. $2{ }^{\circ}$, I) - o que faz todo sentido, dada a sua enorme aptidão para gerar danos relevantes à vida, à integridade física e psíquica, ao patrimônio etc. Por meio do Projeto de Lei do Senado no 272/2016, em sua proposição original, pretendia-se acrescentar dois incisos ao $\$ 1^{\circ}$ do artigo $2^{\circ}$ da Lei $n$ o 13.260/2016, quais sejam: 
VI - incendiar, depredar, saquear, destruir ou explodir meios de transporte ou qualquer bem público ou privado, com o objetivo de forçar a autoridade pública a praticar ato, abster-se de o praticar ou a tolerar que se pratique, ou ainda intimidar certas pessoas, grupos de pessoas ou a população em geral; VII - interferir, sabotar ou danificar sistemas de informática ou bancos de dados, com motivação política ou ideológica, com o fim de desorientar, desembaraçar, dificultar ou obstar seu funcionamento (Brasil, 2016c).

Segundo o Senador Lasier Martins (PSD/RS), propositor da matéria, o inciso VI teria sido inspirado "pela legislação antiterrorista portuguesa". Não há, porém, na lei portuguesa, nada parecido com a tipificação das ações de depredação e saque de bens privados, exceto quanto aos destinados "ao abastecimento e satisfação de necessidades vitais da população" (art. $2^{\circ}, 1$, d, da Lei no 52/2003) (Portugal, 2003). De fato, é difícil imaginar de que forma a depredação da vidraça de um banco - a despeito de ser, indiscutivelmente, uma ação criminosa - atentaria contra as bases do Estado democrático de direito, devendo ser qualificada como terrorista. A propósito, segundo o Supremo Tribunal Federal, nem mesmo o "ataque frontal a um estabelecimento militar, sem utilização de armas de perigo comum nem criação de riscos generalizados para a população civil" (Brasil, 1989) pode ser considerado terrorista - se fosse terrorista, não poderia se qualificar como crime político.

Como citado pelo Senador Randolfe Rodrigues (REDE/AP), em seu voto em separado na Comissão de Constituição e Justiça e Cidadania do Senado Federal, a Nota Técnica - assinada conjuntamente por ARTIGO 19 Brasil, Rede Justiça Criminal, Justiça Global, Instituto de Defensores de Direitos Humanos (DDH), Conectas Direitos Humanos, Instituto de Defesa do Direito de Defesa (IDDD), Instituto Terra, Trabalho e Cidadania, Instituto (ITTC), Sou da Paz e Gabinete de Assessoria Jurídica às Organizações Populares (GAJOP) - apontou que a

[...] nova redação proposta não contempla qualquer diferenciação relativa à natureza essencial dos bens e serviços que se almeja proteger, o que pode resultar na abrangência de todo e qualquer bem ou serviço público como 
passível de ser alvo de ato terrorista, o que não condiz com o mencionado princípio da excepcionalidade. Também vale ressaltar que as novas condutas previstas somam-se a um extenso rol já definido na Lei Antiterrorismo aprovada, que não invoca nenhum tipo de diferenciação na gravidade das condutas tipificadas, cominando a todas essas penas elevadíssimas de reclusão de 12 a 30 anos. Dessa forma, a utilização de armas químicas aptas a promover "destruição em massa" e a depredação de lixeiras ou orelhões públicos (ambas já tipificadas, ressalta-se novamente) podem vir a ser consideradas atos terroristas de igual gravidade e com igual tratamento (Brasil, 2016d, p. 3, grifo nosso).

O mesmo se pode dizer do saque e da destruição (desde que não qualificada por incêndio ou explosão): tais condutas, muito embora reprováveis - inclusive criminalmente -, não atentam contra a democracia em si, uma vez que não visam a violar a ordem pública em sua acepção mais ampla, de ordenação das liberdades (Gomez Torres, 1979). Essas constatações suscitaram, nos movimentos sociais, desconfiança de que o enorme alargamento das condutas abarcadas pelo tipo penal tal como proposto pelo Projeto de Lei do Senado no 272/2016 tem como objetivo criminalizar as suas ações, de forma geral. Isso foi reforçado após a apresentação, pelo então Senador Magno Malta (PR/ES), de emendas ao projeto, uma delas pretendendo alterar o art. $2^{\circ}$ da lei para o seguinte:

Art. 2을 $\mathrm{O}$ terrorismo consiste na prática por um ou mais indivíduos dos atos previstos neste artigo, por razões de xenofobia, discriminação ou preconceito de raça, cor, etnia ou religião, ou por outra motivação política, ideológica ou social, quando cometidos com a finalidade de provocar terror social ou generalizado, expondo a perigo pessoa, patrimônio, a paz pública, a incolumidade pública ou a liberdade individual, ou para coagir governo, autoridade, concessionário ou permissionário do poder público a fazer ou deixar de fazer alguma coisa, por motivação política, ideológica ou social (Brasil, 2018, p. 4, grifo nosso).

Observe-se que, uma vez transformada em lei, a norma proposta ampliaria o tipo penal ao ponto de acrescer aos atos praticados com a "finalidade de provocar terror social ou generalizado" (redação vigente do caput do art. $2^{\circ}$ ) aqueles que têm como objetivo "coagir governo, autoridade, concessionário ou permissionário do poder público a fazer ou 
deixar de fazer alguma coisa" (Brasil, 2018, p. 4). É muito semelhante ao tipo da lei nicaraguense - "[...] quando o propósito do dito ato [...] é [...] obrigar um Governo ou uma organização internacional a realizar um ato ou a abster-se de fazê-lo [...]" (Nicarágua, 2018, tradução nossa), citado acima, e já muito criticado pela Organização das Nações Unidas (ONU).

Essa alteração esbarra numa contradição linguística: da forma como a tipificação é pretendida, poderão ser qualificados como terroristas os atos de coação, mesmo que não "cometidos com a finalidade de provocar terror social ou generalizado" (Brasil, 2018, p. 4). Como já dito aqui, se a ação não visa a provocar o terror, não pode ser tida como terrorista (ao menos em seu sentido material). Ter-se-ia, assim, o absurdo de uma ação terrorista que não visa a provocar o terror.

A discussão sobre a alteração da Lei n.․⒔260/2016 arrefeceu tão logo se dissipou a efervescência das Jornadas de Junho de 2013 e dos protestos contra a realização da Copa das Confederações de 2013, da Copa do Mundo de 2014 e dos Jogos Olímpicos de 2016. Episódios mais recentes, entretanto, reacenderam as discussões sobre o terrorismo. Nos primeiros dias de 2019, ataques violentos realizados por coletivos criminosos ligados ao tráfico de drogas, em confronto direto com o governo do estado do Ceará, trouxeram para a pauta da agenda política a tipificação de determinadas condutas como terroristas. Decerto, isso trouxe consequências para outras esferas sociais, especificamente para os movimentos sociais, uma vez que a Lei no $13.260 / 2016$, se alterada conforme se propôs no Projeto de Lei do Senado no 272/2016, pode ser amplamente interpretada, inclusive de forma discricionária. O poder judiciário não está, de forma alguma, imune a preconceitos políticos.

O contexto em tela traz à tona uma reflexão jurídica sobre a tipificação das condutas das facções como terroristas. Porém, o fenômeno chama ainda atenção para a criminalização dos movimentos coletivos articulados pela sociedade civil em prol da garantia de direitos constitucionais. Note-se que, se, de um lado, coletivos disputam o mercado ilegal da droga e utilizam estratégias notadamente criminosas que provocam terror na cidade, por outro 
lado, é preciso atentar para a reunião coletiva de grupos sociais diversos da sociedade civil que se mobilizam em espaços públicos do país com pautas específicas no intuito de reivindicar suas garantias constitucionais.

O cenário da violência trouxe também para o debate uma reflexão: quanto cada sociedade está disposta a aceitar em restrições aos seus direitos (em especial aos seus direitos fundamentais) em nome do combate estatal à ameaça terrorista? Isso, certamente, é algo difícil de determinar, pois varia conforme o próprio nível de ameaça difusamente percebido, bem como do que é considerado tolerável para cada sociedade, considerando que não são poucos os Estados que se aproveitam de uma fachada de defesa da "segurança nacional" para restringir os direitos de seus cidadãos (Renner; Renner, 2016, p. 9).

Como se vê, a questão é complexa, pois se reflete inclusive nos sentidos de democracia para uma nação. Veja-se então, a seguir, a tônica da violência de 2019 no estado do Ceará promovida pelas facções de tráfico de drogas, que reacendeu os debates sobre a alteração da Lei no 13.260/2016 no Brasil, exigindo do Estado posturas mais rígidas acerca dessas organizações. Portanto, é importante compreender, ainda que brevemente, as práticas e estratégias desses coletivos criminais no estado do Ceará, tomando-as aqui como ações sociais dotadas de sentidos e criatividades por aqueles que a praticam (Weber, 2014).

\section{Facções criminosas no estado do Ceará}

Nos primeiros dias de 2019, no estado do Ceará, ocorreram mais de 200 ataques em 42 dos 184 municípios cearenses, promovidos por coletivos envolvidos com tráfico de drogas. Das ações criminosas, destacamse incêndios a carros particulares, a transportes e veículos utilizados para serviços públicos, além de explosões em postos de saúde e de gasolina, bancos, prefeituras, comércios e prédios públicos, bem como bloqueios de vias urbanas com dejetos e infiltração de explosivos em viadutos, conforme noticiaram diversos veículos jornalísticos à época. Foram também feitas pichações em muros exigindo a exoneração do então secretário da Secretaria 
de Segurança Penitenciária, responsável por propor medidas de fiscalização mais rigorosas no sistema prisional, a exemplo do bloqueio do sinal de celulares no interior das penitenciárias e do fim da divisão das unidades prisionais conforme a facção a que cada preso pertence. A imagem a seguir expõe tais ameaças:

Figura 1. Pichação feita durante ataques no Ceará pede saída do secretário da Administração Penitenciária

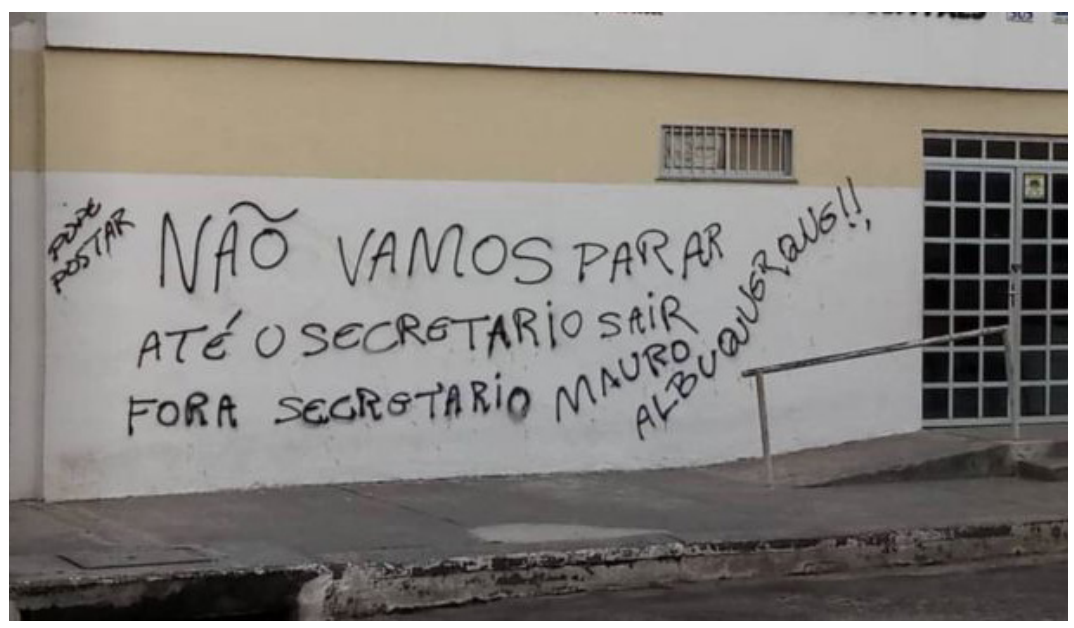

Fonte: Souza (2019).

De acordo com gestores locais, as medidas motivaram uma sucessão de ataques criminosos por meio de facções envolvidas com o mercado de drogas no estado. Trata-se do que Charles Tilly (1978) designa de "repertório de confronto". O termo pode ser usado em situações diversas, mas aqui, em síntese, é pensado a partir das ações desses coletivos, ou seja, práticas movidas por grupos específicos no enfrentamento de opositores e arregimentadas por apoiadores. Ao tratar dessas ações de confronto, Tilly (1978) aponta que diversos mecanismos são acionados, tais como obstrução de vias públicas, passeatas, greves, piquetes, protestos, assim como criação 
de espaços de diálogos nas redes sociais, conforme vem sendo observado nas últimas décadas. Porém, não é só. Há ainda sequestros, depredações, incêndios, xingamentos, paródias, memes cibernéticos, entre outras formas de ação mobilizadas em reivindicações de pequena ou grande escala. Foi o que ocorreu no estado do Ceará no início de 2019, quando "o inimigo comum das facções passou a ser, naquele momento, o Estado. Em vez de briga de facções, passou a ter um denominador comum", afirmou o pesquisador César Barreira, estudioso da temática (Borges, 2019, p. 6).

Para conter as ações das facções, o governo do estado do Ceará recebeu auxílio de tropas da Força Nacional e de policiais militares do estado da Bahia, e promoveu a transferência imediata para presídios federais de 21 membros de facções presos no estado do Ceará. Certamente, o cenário vivido na capital e municípios vizinhos foi aterrorizante. Além das notícias midiáticas, era comum escutar narrativas da população sobre o assunto nos mais diversos espaços da cidade. Além do medo, bairros que sofreram maior número de ataques tiveram serviços de transporte público, entrega de postagens e encomendas, e coleta de lixo suspensos por vários dias. Do senso comum, foram recorrentes as narrativas de que tudo aquilo configurava um cenário de guerra, estando a sociedade diante de atos terroristas. Isso foi ainda reforçado nas falas de autoridades locais, como a do atual Governador do estado do Ceará, Camilo Santana (PT):

[...] precisa de uma mudança. Até porque nesses atos, foi a primeira vez que se usou explosivos em ações no Ceará, bombas. Isso precisa ser tipificado como terrorismo. Precisa o Congresso Nacional rever uma série de leis, inclusive uma delas é essa, a lei antiterrorismo, que precisa tipificar esse tipo de ação como terrorismo (Melo, 2019, grifo nosso).

A narrativa acima coaduna-se ao pensamento do Ministro da Justiça e Segurança Pública do país à época, Sérgio Moro, ao afirmar, em entrevista ao canal televisivo Globo News, no dia 15 de fevereiro de 2019, que, no estado do Ceará, "organizações criminosas se sentiram à vontade de praticar verdadeiros atos terroristas" (Moro, 2019 apud Melo, 2019). Também se observa juízo semelhante do Presidente Jair Bolsonaro, que, ao pronunciar- 
se no Twitter, no dia 12 de janeiro de 2019, afirmou, ao tratar dos atos criminosos praticados no estado do Ceará, que seria preciso enrijecer a legislação penal:

Ao criminoso não interessa o partido desse ou daquele governador. Hoje ele age no Ceará, amanhã em SP, RS ou GO. Suas ações, como incendiar, explodir... bens públicos ou privados, devem ser tipificados [sic] como TERRORISMO. O PLS 272/2016 do Sen. Lasier Martins é louvável (Bolsonaro, 2019).

No cerne de tudo isso, algumas questões emergem: quem são esses sujeitos coletivos envolvidos com tais ações violentas? Como tais práticas criminosas foram se configurando no Ceará? Do ponto de vista normativo, quais as possibilidades de tipificação das ações das facções como atos terroristas?

De acordo com Paiva (2019, p. 165), a história da violência em Fortaleza, capital do Ceará, é marcada por "transformações sociais nas maneiras de fazer o crime na cidade." Ao buscar compreender tal questão, o pesquisador toma como ponto de partida o trabalho de Diógenes (2008), que aponta a dinâmica das gangues nas periferias de Fortaleza nos anos 1990, quando "grupos de jovens criavam seus repertórios para demonstrar, publicamente, que 'se garantem', compartilhando códigos constitutivos de uma linguagem própria e maneiras peculiares de estabelecer suas relações dentro e fora do território" (Paiva, 2019, p. 171).

Pensando um pouco antes dos anos 1990, tem-se que, entre as décadas de 1960 e 1980, as preocupações em torno da violência no estado do Ceará eram sobre crimes de pistolagem, isto é, de pessoas com morte encomendada por motivações de vingança, envolvendo especialmente brigas de família e conflitos trabalhistas. No limiar dos anos 1980, e, sobretudo, nos anos 1990, novas dinâmicas foram emergindo, notadamente nas periferias da cidade, sendo os conflitos por território, entre algumas gangues, o ponto crucial de homicídios entre jovens, afirma Paiva (2019). Segundo o autor, naquele contexto histórico, a inserção de drogas e armas na periferia não tinha como objetivo a constituição de um mercado ilegal, 
mas ser subsídio aos confrontos territoriais entre gangues, aumentando assim a letalidade do conflito e garantindo a capacidade de confronto, tendo a violência como tônica.

No entanto, o comércio ilegal de drogas mostrou-se rentável e, assim, os conflitos ganharam nova roupagem, de forma que pessoas com posições de destaque nas gangues tornaram-se chefes do tráfico. Esses, nas primeiras configurações do tráfico na cidade, passaram a estabelecer seu domínio nas comunidades e a marcar os territórios. Ultrapassar tais limites espaciais imaginários resultava em morte. Desenhava-se, por conseguinte, a dinâmica do tráfico na cidade. Os chefes desse comércio ilícito, antigos líderes de gangues, viam no mercado de drogas um mecanismo importante de manutenção dos confrontos territoriais. Os moradores da comunidade, por sua vez, viam a venda da droga como possibilidade de fazer negócios, transformando suas casas nas chamadas "bocas de fumo".

No início dos anos 2000, outros elementos marcaram a tônica da violência, desencadeando um processo de organização da criminalidade em torno de disputas pelo mercado de drogas, em que grupos de pessoas envolvidas com ilegalidades organizavam-se a partir da noção de facção. Assim, no decorrer das três últimas décadas, coletivos criminosos rivais foram se territorializando no estado do Ceará, marcando um novo contexto na cidade a partir de grupos locais associados a outros de dimensão nacional, com origem em São Paulo e no Rio de Janeiro: o Primeiro Comando da Capital (PCC) e o Comando Vermelho (CV). Outras duas forças de atuação importantes que hoje figuram no nordeste do país, inclusive no estado do Ceará, são a Família do Norte (FDN), oriunda do sistema prisional amazonense, e a Guardiões do Estado (GDE), fundada em 2016 no próprio estado do Ceará, e que congrega, de modo geral, pessoas inseridas no crime, detentos e egressos do sistema prisional (Paiva, 2019).

Decerto, as formas de fazer o crime são atravessadas por uma variedade de movimentos, regras, ilegalidades, negociações, enfrentamentos, hierarquizações, estratégias de demarcação de territórios, ações e formas de reivindicação de sua organização coletiva sob o título, por exemplo, de 
facção - categoria nativa perpassada de sentidos e ponderações conceituais, sendo aqui tomada como

[...] coletivo constituído por associações, relacionamentos, aproximações, conflitos e distâncias necessárias entre pessoas comprometidas em fazer o crime, desenvolvendo relações afetivas profundas, laços sociais elaborados como os de família, e um sentimento de pertença desenvolvido pela carência em determinadas orientações políticas e éticas que a sustentam. São coletivos móveis de pessoas que fazem o crime como um meio de integrar a sociedade, pois não visam à sua destruição, e sim à participação em um sistema de bens materiais e simbólicos agenciados de múltiplas maneiras. Em alguma medida, as facções são coletivos compostos por convergências de intencionalidades de alcances variados, com pessoas ocupando posições privilegiadas nos esquemas do coletivo e outras atuando em suas margens (Paiva, 2019, p. 170).

Portanto a ideia que parece mais adequada é compreender a noção de facção dentro de um campo de possibilidades, percebendo seus movimentos internos, além das tensões e sentidos que toma levando em conta contextos e temporalidades sociais. São redes que "podem ser descritas na sua conformação mais generalizante por meio de uma 'geometria de escalas variáveis [...]'", articulando pessoas que se situam em posições específicas quanto às negociações e processos de circulação das mercadorias, conforme apontam Hirata e Grilo (2017, p. 79).

Logo, as maneiras de fazer o crime não são únicas, universais e generalizáveis, mas permanentemente passíveis de transformações, de forma que as dinâmicas se territorializam tanto em bairros periféricos como naqueles de elevada concentração do poder aquisitivo, além de agregarem pessoas com distintos perfis sociais. O crime faz-se, então, como a "tática de praticantes que desenvolvem maneiras de fazer fragmentadas, experimentações complexas e agenciamentos possíveis" (Paiva, 2019, p. 167).

No estado do Ceará, dentre as estratégias mais utilizadas nos confrontos pelo domínio do mercado de drogas, verificam-se, com maior frequência, o controle de territórios, o estabelecimento de regras rígidas para a comunidade, a aplicação de punições com requintes de crueldade (inclusive com exposição nas redes sociais), a ampliação do poder de 
fato - que extrapola a localidade, avançando também sobre o interior dos presídios -, o uso de armas potentes, como o fuzil e aquelas de calibre com aptidão para atravessar vidros blindados, sobretudo nos confrontos com a polícia. Assiste-se, ainda, a torturas contra quem desobedece aos códigos de conduta estabelecidos, bem como a chacinas, paralisações em escolas, abandonos de equipamentos públicos, invasões a territórios do inimigo, homicídios, expulsões de famílias inteiras de bairros, além da arregimentação de jovens em situação de extrema vulnerabilidade social.

Dado o contexto das últimas décadas, populações situadas nas áreas mais periféricas da cidade de Fortaleza, onde há a maior concentração das facções criminosas, passaram a adaptar-se às novas dinâmicas sociais do crime. Ainda que a esmagadora maioria dos moradores de periferia busque seu sustento fora do mercado ilegal de drogas, foi preciso obedecer a regras estabelecidas no território onde vivem para garantir algum tipo de sobrevivência.

Assim, marcados por ilegalidades, tais coletivos ora afastam-se e rivalizam na disputa do mercado de drogas, ora suspendem as rivalidades e aproximam-se, movidos por interesses comuns. Em relação ao Estado, ora buscam estabelecer acordos, ora tomam-no como inimigo comum. Exemplo disso ocorreu em 2016, quando coletivos criminosos tentaram estabelecer entre si um acordo de irmandade para a "pacificação" do estado do Ceará, ou seja, acordos pela "paz" entre facções rivais que resultariam na significativa redução do crime na cidade. A proibição dos assaltos nas periferias foi estratégia crucial para garantir uma aparente legitimidade aos traficantes e produzir a ideia de que as comunidades estavam seguras.

De fato, naquele ano, houve significativa redução do número de homicídios, 15,2\% menor se comparada ao ano de 2015, segundo indicam os dados da Secretaria de Segurança Pública e Defesa Social do Estado do Ceará (SSPDS). Porém, em março de 2016, os conflitos exacerbaramse, tendo como estopim a Lei estadual no 15.984/2016, que proibiu o "sinal de radiofrequência em áreas destinadas às Unidades Prisionais do Estado do Ceará, de modo a impedir a comunicação por telefones móveis no interior destas" (Ceará, 2016). A partir de então, ataques ao 
patrimônio público, ameaças a lideranças do estado e rebeliões dentro dos presídios representaram indícios de que a "paz" estava com os dias contados, anunciando confrontos entre o PCC e o CV, que resultariam, em 2017, no "maior conflito armado vivido no Estado do Ceará, repercutindo em 5.134 crimes violentos, letais e intencionais" (Paiva, 2019, p. 176).

As ações criminosas que assolaram o Ceará no início de 2019 expuseram os modos de agir de sujeitos ligados ao mercado de drogas, apontando as aproximações, tensões e enfrentamentos desses coletivos com o Estado. Outro aspecto é que a explosão de atos violentos nos meses iniciais de 2019 se revelou não um fato isolado, criado de forma improvisada, mas sim o reflexo de conflitos muito profundos arraigados na prática da violência no estado do Ceará, mostrando ainda as falhas no modus operandi do poder público quanto à segurança pública, dada a negligência dos gestores relativa à desarticulação do crime organizado no estado. Historicamente, veem-se basicamente investimentos em policiamento ostensivo, porém sem planos estratégicos específicos com foco no controle social das áreas mais atingidas, nem implementação de projetos educacionais e sociais efetivos que confiram a crianças e jovens sentidos de vida, pertencimento e esperança de dias prósperos. Note-se que, em 2016, o governo do estado do Ceará negou que a redução dos homicídios na cidade fosse resultado do pacto estabelecido entre as facções, apontando ser resultado do trabalho das forças de segurança, afirma Paiva (2019).

Nos bairros com maiores níveis de Índice de Desenvolvimento Humano (IDH), ${ }^{4}$ os confrontos entre as facções parecem algo distante, como se seus habitantes estivessem protegidos em seus territórios. Isso decorre do permanente policiamento ostensivo nas áreas mais nobres, onde se concentram as maiores movimentações turísticas. Não obstante,

\footnotetext{
${ }^{4}$ Segundo a Secretaria Municipal de Desenvolvimento Econômico de Fortaleza, há bairros com IDH muito alto (acima de 0,8$)$, como o Meireles $(0,953)$, a Aldeota $(0,867)$ e o Dionísio Torres $(0,860)$. Na outra ponta, há bairros com IDH extremamente baixo (sendo o baixo inferior a 0,55), como o Conjunto Palmeiras $(0,119)$ (Fortaleza, 2014). A realidade é díspar. Para se ter uma referência, a "Belíndia" refere-se a uma diferença de IDH de 0,919 (Bélgica) para 0,647 (Índia) (Programa das Nações Unidas para o Desenvolvimento, 2019).
} 
os acontecimentos do início do ano mobilizaram a cidade como um todo, uma vez que os ataques ocorreram em diversos espaços, afetando não somente moradores de áreas mais vulneráveis. O quadro de conflitos chamou a atenção para a complexidade do fenômeno da violência no estado do Ceará, apontando que os mecanismos de ação do crime não são estáticos, nem redutíveis a um único agente, nem localizados em um único território.

Assim, ainda que regras sejam definidas e estabelecidas pelo poder público, a reprodução do crime pelas facções é permanentemente atualizada, sendo capaz de inverter regras, conferir sentidos não previstos, atualizar a lógica de espacialidade dos territórios que formam a cidade. Como já apontado aqui, o contexto de ações violentas no estado do Ceará em 2019 desembocou na busca ávida pela alteração da Lei no 13.260/2016, trazendo ao debate o fato de as práticas realizadas por sujeitos coletivos não serem apenas aglomerações na cena pública, mas atos que poderiam ser tipificados como crime. Contudo, é preciso observar-se que há distinções marcantes quando se comparam ações dos coletivos criminais com as práticas de movimentos sociais historicamente constituídos no país, assim como há singularidades entre movimentos sociais centrados em ideias mais clássicas e novos atores que têm surgido nos últimos anos em torno da expressão coletivos, conforme será tratado a seguir.

\section{Movimentos sociais, manifestações e coletivos em cena}

Historicamente, assiste-se, em diferentes localidades do mundo, à dinâmica de sujeitos que se lançam às ruas reivindicando pautas específicas. Com a radicalização da globalização, essas práticas complexificaramse, adquirindo novos repertórios de ação e formas de pressão política, sendo notórias as articulações a partir das redes sociais, especialmente nos anos 2000, conforme se verifica no Brasil. As configurações das ações desses sujeitos coletivos são diversificadas: desde práticas estruturadas e configuradas em torno de identidades mais coesas, até aquelas que 
adquiriram novas lógicas nas últimas décadas, ou seja, fragmentadas e temporárias, impulsionadas por questões circunstanciais. De um modo geral, essas práticas coletivas são atravessadas pela multiplicidade de identidades, de posturas ideológicas e formas de enfrentamento em relação ao Estado. Algumas contam com recursos financeiros de órgãos não governamentais (nacionais e internacionais), enquanto outras se organizam a partir de esforços próprios. As dimensões de articulação também variam: a Parada do Orgulho Gay, criada em 1995, é um exemplo para pensar como uma organização social se articula simultaneamente em diferentes níveis (local, nacional e transnacional).

Todas essas dinâmicas colocam desafios para apreender quem são essas pessoas, a partir de quais elementos os grupos se estruturam, permanecem mobilizados ou se dissipam, assim como a natureza de suas ações e quais questões colocam ao Estado, dada a força da pressão social de alguns deles. Outro aspecto são as questões conceituais, em razão do volume de expressões que emergem, mobilizadas pelos próprios sujeitos, pela mídia e pela sociedade civil de forma mais ampla: atos, ondas, coletivos, protestos, mobilização, movimentos sociais, movimentos comunitários, associações civis, comunidades virtuais, ativismo, militância, balbúrdia, entre outros.

Considerando as manifestações de rua no Brasil na última década, Gohn (2016) afirma que são parte de novas formas de movimentos sociais, sendo o termo "manifestação de protesto" o mais adequado para pensar o que houve em junho de 2013. Para a autora, essas novíssimas formas são algo completamente diferente dos movimentos clássicos operários, agrários e sindicais ou ainda dos emancipatórios de luta por direitos e oposição a regimes autoritários, como ocorreu na América Latina nos anos 1970 e 1980, apoiados por segmentos do cristianismo; também são bastante diferentes dos movimentos da segunda metade do século XX, cujas formas de organização fugiam às estruturas rígidas dos movimentos operários.

Para Gohn (2016, p. 3), diferentemente dos movimentos sociais, a dinâmica das manifestações aproxima-se mais da ideia de multidão, uma categoria mais contemporânea: "o sujeito social integrante de uma multidão 
é diferente, múltiplo (tem várias identidades) e ativo, agindo segundo as singularidades do [grupo] no qual participa e se identifica [...]".

De tudo isso, uma questão importante para se pensar aqui está relacionada às motivações desses coletivos, por vezes orientados pelas práticas de violência - conforme se percebe a partir das ações das facções criminosas -, por vezes mobilizados pelo forte apelo popular. Veja-se que, nas manifestações de junho de 2013, milhares de pessoas saíram às ruas, em diferentes localidades do país, tendo como pauta inicial o aumento da tarifa dos transportes públicos, ampliando a agenda de reclamações para inúmeras outras áreas do serviço público, conforme explicitado no tópico anterior.

Em meio às Jornadas de Junho de 2013, outras manifestações - já parte de outros movimentos sociais atuantes nas últimas décadas - ocorreram paralelamente e chegaram a a se mesclar, trazendo à tona valores importantes para grupos sociais específicos, a exemplo da moradia, questões de gênero e sexualidade. Nessas configurações, chamava a atenção o protagonismo das juventudes e o caráter fluido da mobilização, sem destaque para lideranças específicas, ainda que alguns atores, situados em movimentos sociais antigos ou recém-criados, tenham tido destaque na cena, a exemplo do Movimento dos Trabalhadores Sem Teto (MTST), o Vem Pra Rua e o Movimento Passe Livre (MPL), com forte atuação na mobilização e convocação às ruas. Registre-se que a mídia televisiva e a internet tiveram papel importante como articuladoras no que diz respeito ao estabelecimento de locais, datas e horários, afirma Gohn (2016). Após junho de 2013, essas manifestações perderam força em termos de mobilização de massa, havendo ativações, sobretudo nas redes sociais, em torno de pautas específicas, como, por exemplo, a crítica à realização no Brasil da Copa do Mundo de 2014, dando ênfase aos exorbitantes gastos com infraestrutura.

Em 2015, a multidão voltou às ruas. Com características distintas de 2013, congregavam novas camadas sociais, notadamente as classes médias. No centro das reivindicações, ganhavam fôlego os protestos contra a corrupção, tendo centralidade aquela relacionada à Petrobras, investigada na 
operação Lava a Jato, da Polícia Federal. De um lado, grupos questionavam a permanência de Dilma Rousseff (PT) na Presidência da República; de outro, grupos levavam às ruas suas demandas, mas não apoiavam o impeachment (Gohn, 2016). Dentre os últimos, registre-se a atuação do Movimento dos Trabalhadores Sem Terra (MST), do Movimento dos Trabalhadores Sem Teto (MTST), da Central Única dos Trabalhadores (CUT), da União Nacional dos Estudantes (UNE), que apresentaram reivindicações, mas ainda apoiavam o governo federal. Note-se, ainda, que o papel das redes sociais foi fundamental em 2015, no que diz respeito às mobilizações sociais.

No entanto, a violência também entrou em cena: tanto em 2013 como em 2015, vitrines e bancos foram depredados, transportes públicos incendiados, pessoas presas com truculência pela polícia. Como aponta Charles Tilly (1978), em movimentos de grande escala, configurados por interesses díspares, é comum que, por vezes, indivíduos se misturem à massa com o propósito de promover atos criminosos. Com isso, a sociedade teve um contato mais próximo com aqueles conhecidos como black blocs, ${ }^{5}$ que, no imaginário popular, assumiram "o papel de hooligans das liberdades públicas" (Sarlet; Weingartner Neto, 2014, p. 491).

As cenas de violência, somadas às imagens das multidões nas ruas, construíram representações diversas sobre as manifestações sociais, apontando que tais aglomerações promoviam desordem social, prejudicavam o direito de ir e vir e colocavam em risco a integridade física das pessoas e a manutenção do patrimônio público e privado. Portanto, desse ponto de vista, seria preciso mais rigor jurídico para conter movimentos de multidão ou agrupamentos que se lançassem às ruas com fins de contestação da ordem posta.

5 "Os grupos se caracterizam por usar roupas e máscaras negras cobrindo o rosto, para dificultar a identificação por parte de autoridades. O vestuário também cria uma sensação de conjunto e união entre si. A ideologia Black Bloc se baseia no questionamento da 'ordem vigente'. Eles se manifestam contra o capitalismo e a globalização. Suas ações promovem o dano material a fachadas de empresas multinacionais e vidraças de bancos, por exemplo. Por esse motivo são geralmente associados à violência e depredação. Acabam, na maioria das vezes, entrando em confronto com a polícia. O ativismo Black Bloc tem origem na Alemanha, na década de 1970, e seguidores em diversos países. Não é, entretanto, um movimento de organização única. Em uma mesma manifestação, por exemplo, pode haver grupos distintos, com organização e táticas diferentes." (Entenda..., 2013). 
Se, em 2013, alguns ânimos se exaltaram diante das cenas de violência, clamando pela tipificação de determinadas condutas de massa como atos terroristas, o debate ganhou novamente fôlego no ano seguinte, por ocasião da Copa do Mundo, realizada no Brasil (Saint-Pierre, 2015). Foi reanimado em 2015, quando, no período preparatório para a realização dos Jogos Olímpicos do Rio de Janeiro de 2016, recrudesceu principalmente no momento em que foi apresentado ao Congresso Nacional o anteprojeto que, ao final, resultou na Lei no 13.260/2016.

Se interpretada no contexto pós-Jornadas de Junho e dos acalorados debates ocorridos a partir de então, compreende-se a iniciativa contra o terrorismo como uma forma de repressão endereçada: veja-se, por exemplo, as leis dos estados de Alagoas (2015), Amazonas (2014), Mato Grosso (2014), Minas Gerais (2014), Rio de Janeiro (2013) e São Paulo (2014), e do município de Porto Alegre (2014), todas editadas entre 2013 e 2015, e todas restringindo, de alguma forma, o direito de livre reunião e manifestação. ${ }^{6}$

A profusão de leis objetivando intervir de alguma forma nos movimentos sociais demonstra que eles não estão, de forma alguma, a salvo de uma cruzada estatal contra a "ameaça terrorista" - seja diretamente, com a criminalização de suas ações típicas, seja indiretamente, a reboque da qualificação, como terroristas, de atos tais como os praticados pelas facções criminosas no estado do Ceará, no início do ano de 2019.

Do cenário em tela, algumas questões ganham destaque e merecem ser pensadas com cuidado. Uma delas é a dimensão de generalização que práticas movidas por sujeitos coletivos adquirem. Conforme foi apresentado, atos, movimentos sociais, coletivos e manifestações sociais têm especificidades. Veja-se que, diferentemente dos movimentos sociais, os coletivos desenham seus contornos de forma mais fluida, em oposição a estruturas tradicionais e mais centralizadoras (Gohn, 2016). De acordo com Gohn (2016), um coletivo não necessariamente desenvolve práticas

${ }^{6}$ Segundo Peixoto (2019), sete delas dizem respeito ao uso de máscaras, seis estabelecem algum tipo de intervenção estatal, cinco regulamentam o aviso prévio, uma prevê a cobrança pelos custos das medidas administrativas, uma designa local para realização de manifestações. 
contestatórias, diferentemente dos movimentos sociais, que têm identidades mais coesas, opositores mais bem definidos e são constituídos a partir das trajetórias de seus membros, que neles se envolvem tendo-os, por vezes, como projeto de vida. Nos coletivos, os sujeitos

[...] autodenominam-se como ativistas, vivem experiências e experimentações, que podem ser tópicas ou mais permanentes; fragmentadas ou mais articuladas. Os membros participantes de um movimento social são militantes de uma causa, é algo mais que um ativista porque não foi convocado online, ad hoc. Ele tem laços de pertencimento com um grupo. Um coletivo pode se transformar em movimento social, ou autodenominar-se movimento, ou articular-se a um conjunto de outros coletivos que configuram um movimento social. Ou negar a forma movimento social por considerá-la presa aos modelos tradicionais de fazer política (Gohn, 2016, p. 4-5).

Porém, ainda que guardem semelhanças entre si, há aspectos que delimitam suas fronteiras. Quando se pensa de forma individualizada, as particularidades também ganham força. Mesmo que um objetivo comum tenha centralidade, a multidão atrai pessoas com motivações, valores morais e emoções diversas, a exemplo da prática da violência e destruição de patrimônio público. Certamente, a indignação pode ser o gerador de comoção, levando milhares de pessoas aos espaços públicos. ${ }^{7}$ Contudo, isso não significa que a violência seja o repertório adotado, como se viu com os black blocs.

Outro ponto fundamental é a participação popular, aspecto fundamental para a manutenção de uma democracia. Dialogar, negociar e exercer mecanismos de pressão com o Estado nas lutas por cidadania tem sido cada vez mais necessário em sociedades globalizadas, plurais, multiculturais e multiétnicas. Portanto, nada mais legítimo que o pleito por mudanças constitucionais que já não mais atendem a novas configurações das famílias contemporâneas; por respeito às diferenças no que toca às múltiplas dimensões de gênero e sexualidade que atravessam os indivíduos; por direitos reprodutivos; pela preservação do meio ambiente; por questões de igualdade racial e social, entre tantas outras fortemente presentes na

${ }^{7}$ Sobre a categoria indignação, ver Gohn (2016). 
formação da sociedade brasileira. Assim, as ações coletivas em prol de direitos individuais expressam significados sobre formas de ser e estar no mundo de sujeitos diversos.

Logo, os debates em torno da tipificação de determinados atos violentos como terroristas, a exemplo das ações das facções no Ceará, têm rebatimentos diretos na democracia, cujos possíveis efeitos podem recair na possível criminalização de movimentos organizados pela sociedade civil em prol da garantia de direitos constitucionais, como a própria segurança pública. Diante disso, cabe entender o seguinte: qual a importância de manifestações sociais e os possíveis efeitos da alteração da Lei no 13.260/2016 para a democracia brasileira?

\section{A alteração da Lei $n^{0}$ 13.260/2016 e os impactos na democracia}

O clamor popular pela modificação da Lei no $13.260 / 2016$, para tipificar as ações das facções ocorridas nos primeiros dias de 2019 como "terroristas" é explicável em razão de, sob a ótica jurídica, elas não serem abrangidas pelo tipo daquela lei, pois não foram praticadas "por razões de xenofobia, discriminação ou preconceito de raça, cor, etnia e religião" (Brasil, 2016a), e tampouco descritas nos incisos I a V do dispositivo tipificador:

[...] I - usar ou ameaçar usar, transportar, guardar, portar ou trazer consigo explosivos, gases tóxicos, venenos, conteúdos biológicos, químicos, nucleares ou outros meios capazes de causar danos ou promover destruição em massa; II (VETADO); III - (VETADO); IV - sabotar o funcionamento ou apoderar-se, com violência, grave ameaça a pessoa ou servindo-se de mecanismos cibernéticos, do controle total ou parcial, ainda que de modo temporário, de meio de comunicação ou de transporte, de portos, aeroportos, estações ferroviárias ou rodoviárias, hospitais, casas de saúde, escolas, estádios esportivos, instalações públicas ou locais onde funcionem serviços públicos essenciais, instalações de geração ou transmissão de energia, instalações militares, instalações de exploração, refino e processamento de petróleo e gás e instituições bancárias e sua rede de atendimento; $\mathrm{V}$ - atentar contra a vida ou a integridade física de pessoa (Brasil, 2016a). 
Há, assim, uma grande e inegável divergência entre a tipificação legal e a concepção material de terrorismo - divergência que poderia ser sanada pela aprovação do Projeto de Lei do Senado no 272/2016, com suas emendas. No entanto, sob a ótica social, dos movimentos sociais, a eventual aprovação do projeto de lei causaria impactos enormes, ainda maiores que a ameaça subjacente à própria Lei no $13.260 / 2016$, em decorrência de suas "expressões indeterminadas e maleáveis, capazes de comportar, de acordo com a ideologia e vontade do intérprete, condutas e contextos dos mais diversos possíveis" (Cambi; Ambrosio, 2017, p. 1377).

Já desde a época da discussão parlamentar sobre o texto original ${ }^{8}$ - hoje sancionado - da Lei no 13.260/2016, os movimentos sociais manifestavam profunda preocupação com a dação ao poder público de um poder de interferir sobre suas liberdades democráticas; por exemplo, um deputado chegou a destacar que "experiências internacionais com projetos de lei antiterrorismo mostram que esse tipo de legislação acaba por atingir e reprimir movimentos sociais" (Dichtchekenian, 2015). Como se noticiou, naquele momento, grupos de direitos humanos temiam que houvesse "uma brecha interpretativa para criminalizar esses movimentos" (Dichtchekenian, 2015). Assim, durante todo o período de debate parlamentar, "organizações da sociedade civil e movimentos sociais mobilizaram-se contra sua aprovação" (Marques; Rielli, 2016).

Ao final, conquistou-se uma expressa ressalva na lei, excluindo sua aplicação a

[...] pessoas em manifestações políticas, movimentos sociais, sindicais, religiosos, de classe ou de categoria profissional, direcionados por propósitos sociais ou reivindicatórios, visando a contestar, criticar, protestar ou apoiar, com o objetivo

\footnotetext{
${ }^{8}$ A preocupação é mesmo anterior. Guedes (2014, p. 51), antes mesmo da apresentação do projeto de lei que resultou na Lei no 13.260/2016, já destacara, sobre projeto anterior (Projeto de Lei do Senado no 499/2013), que o "[...] principal empecilho à votação do PLS 499/2013 foi a avaliação, dominante entre os senadores, de que a proposta precisava ser modificada para evitar que manifestações de movimentos sociais viessem a ser enquadradas como atos de terrorismo".
} 
de defender direitos, garantias e liberdades constitucionais, sem prejuízo da tipificação penal contida em lei [art. $2^{\circ}$, § $2^{\circ}$ ] (Brasil, 2016a).

Além disso, alguns dispositivos do texto aprovado pelo Congresso Nacional foram objeto de veto presidencial (Brasil, 2016b). A aposição desses vetos deixou irresignada parte do Congresso Nacional, que desejava a dação ao poder público de oportunidades ainda mais intensas de intervenção em ações de movimentos sociais - em especial considerados os fatos ocorridos um pouco antes, durante as Jornadas de Junho de 2013. É nesse contexto que deve ser entendido o Projeto de Lei do Senado no 272/2016, como amplamente discutido anteriormente.

Certamente, a lei coloca possibilidades de atuação, estabelece limites aos agentes. Contudo, sujeitos articulam-se, trocam ideias, avaliam interesses comuns, negociam tensões e mobilizam historicamente repertórios diversos para atingir seus objetivos de confronto. Assim, situados em um campo tensionado, sujeitos coletivos se enfrentam (explicitamente ou não) contra um opositor comum, por vezes, o Estado.

Por exemplo, no estado do Ceará, proliferam os coletivos em prol de exigências de segurança pública. Em 2017, foi lançado, na cidade de Fortaleza, o Fórum Popular de Segurança Pública, como espaço de articulação de entidades, pesquisadores e movimentos sociais com o propósito de ser um canal de debates, monitoramento, denúncias e formulação de proposições no âmbito das políticas de segurança pública. $\mathrm{O}$ foco de atenção é discutir um Plano Nacional de Segurança Pública, um marco federativo que estabeleça o papel da União, dos estados e dos municípios, com fontes precisas de financiamento de cada ente, além de promover visibilidade para a importância da participação popular no campo das políticas de segurança. O Fórum reflete ainda sobre medidas punitivas atinentes ao aumento de mortes envolvendo policiais em chacinas, como ocorreu no dia 11 de novembro 2015, quando 44 policiais foram denunciados pelo massacre ocorrido em Messejana, bairro da cidade de Fortaleza. 
Outra articulação importante no estado do Ceará, instituída em 2016, foi o Comitê Cada Vida Importa. Em parceria com o governo do estado, com o Fundo das Nações Unidas para a Infância (UNICEF) e com outras instituições do poder público e da sociedade civil, o objetivo central é a prevenção de homicídios entre adolescentes. Após apresentação do relatório em que foram ouvidas 224 famílias de adolescentes assassinados, o Comitê se centrou em propor recomendações para o poder público que reduzissem a violência letal contra meninos e meninas de 10 a 19 anos.

O movimento Fortaleza Apavorada, criado em 2013, levou manifestantes às ruas da cidade com concentração em frente ao Palácio da Abolição, sede do governo do estado do Ceará. Bloqueando as ruas e entoando gritos de guerra, como "Senhor governador, segurança, por favor!" e "O povo se cansa, exige segurança!", os manifestantes elevavam cartazes clamando por ações mais efetivas contra o crescimento da violência urbana.

A questão que mobiliza reflexões é que, paradoxalmente, a nova tipificação proposta abarcaria até mesmo atos praticados por esse movimento social, uma vez que, mesmo sem o intuito de gerar o terror generalizado, são praticados com objetivo de "coagir governos" - tal como consta no Projeto de Lei do Senado no 272/2016. Certamente, conflitos, articulações e negociações entre Estado e sociedade civil provocam rebatimentos no campo teórico. Do ponto de vista epistemológico, é nítido o confronto de ideias em torno de dois paradigmas no bojo da teoria democrática: o do consenso e o do conflito. Se, por um lado, correntes de pensamento bradam a importância do consenso e da ordem para manutenção da democracia; de outra perspectiva, escolas de pensamento argumentam a favor do conflito, afirmando que é desafiando as estruturas de poder vigentes que se pode vislumbrar uma sociedade democrática balizada por parâmetros emancipatórios. Santos (2007, p. 97), por exemplo, propõe explicitamente a realização de uma pressão ilícita, em resposta ao fechamento das vias de contestação direcionada ao governo. Segundo ele, "com a criminalização da contestação está se reduzindo a possibilidade de uma luta institucional, e se esta se reduz temos de abrir espaços para a possibilidade de uma luta direta, ilegal e pacífica". 
É importante, ainda, nesse contexto, destacar o que Castilho e Feitosa (2016, p. 1023) observaram: que, em especial, em sociedades como a brasileira, os atos praticados pelos movimentos sociais têm aptidão para pressionar "as estruturas de poder, institucionalizadas ou não, frente à necessidade de concretização de uma ordem democrática pautada pela justiça social." Assim, em um estado democrático - e isso é ainda mais importante no Brasil, dadas as peculiaridades de sua democracia -, não se podem

[...] cercear as liberdades públicas e privadas, nem calar os dissidentes políticos que, no exercício de seu direito constitucional de oposição [...], não apenas poderão divergir, mas se opor pacificamente, por meio de manifestações públicas e de gestos simbólicos, às decisões majoritárias, em nome do aprofundamento e prosseguimento dos debates públicos, do respeito aos direitos fundamentais e do próprio regime democrático constitucional, em face da inércia dos poderes estatais e das organizações sociais e econômicas. As oposições, os dissidentes políticos e os desobedientes civis não podem ser confundidos com criminosos políticos e com inimigos da Constituição que de forma violenta, intolerante, fundamentalista e subversiva atentarem contra o regime democrático (Oliveira, 2013, grifo nosso).

Essa observação confirma o que se vem afirmando: a importância da participação popular, em suas distintas formas de organização, sejam as mais clássicas como os movimentos sociais, sejam as mais atuais como os coletivos, para o aprimoramento da democracia brasileira, sendo por consequência inconstitucional qualquer norma que vise a criminalizar, de forma genérica, as suas ações.

\section{Considerações finais}

A questão central do presente artigo recai nos possíveis efeitos das alterações da Lei no 13.260/2016 (Lei Antiterrorismo) pelo Projeto de Lei do Senado no 272/2016. Elas trariam não somente a tipificação de determinadas condutas como atos terroristas, mas impactariam sobretudo as liberdades constitucionais asseguradas a práticas coletivas organizadas em torno de manifestações, protestos, movimentos sociais, coletivos, dentre outras organizações que se movem para a luta de direitos diversos, 
como saúde, cultura, educação, habitação, segurança pública, garantias trabalhistas, sanitárias, direitos reprodutivos, além das lutas de gênero e respeito à diferença.

Essas questões são apresentadas no artigo a partir de uma inquietação inicial: a força dos discursos que circularam no início de 2019, quando facções envolvidas com o mercado ilegal de drogas promoveram atos de violências em diversas localidades do Ceará, levando a exigências da sociedade civil por mais rigor na lei. Esse anseio associava-se à ideia de que a ordem pública somente poderia ser mantida se existissem tipos severos que criminalizassem os atos intuídos como terroristas, que colocavam em risco não somente a vida, mas também o direito de ir e vir das pessoas, já que, no contexto, à época, diversos serviços foram paralisados. Registrese que ocorreram incêndios, depredações em equipamentos públicos e privados, além de explosões com dinamite em viadutos que interligam pontos importantes entre os municípios.

Contudo, para uma correta compreensão dos impactos que podem advir da alteração proposta da Lei no 13.260/2016, é necessário ampliar o foco, para alcançar também o contexto das mobilizações de multidão ocorridas no país, especialmente entre 2013 e 2015. Esses eventos como as Jornadas de Junho de 2013, os protestos contra a realização da Copa das Confederações, no mesmo ano, contra a Copa do Mundo, em 2014, contra e a favor do impeachment, em 2015, e contra os Jogos Olímpicos de 2016 - levaram milhões de pessoas aos espaços públicos de suas cidades, mobilizadas por questões subjetivas diversas, mas comungando da insatisfação com os serviços públicos. Se, por um lado, surgiam discursos apontando a importância de tais ações, como pilares de uma democracia forte; por outro lado, circulavam falas distintas apontando toda mobilização como caos, desordem e balbúrdia, termo inclusive bastante retomado em 2020. Surgiram nas redes sociais comentários e memes indicando que manifestações que tomam as ruas atrapalham o funcionamento da sociedade, impedem que serviços de emergência realizem seus fluxos com eficiência, como as ambulâncias e carros de bombeiros, além de provocarem um cenário caótico diante do barulho, do volume de lixo nas ruas e das depredações e/ou danificações de equipamentos e patrimônios públicos. 
É necessário ter em mente que o anseio por aumento do rigor penal contra os atos praticados por facções criminosas se reflete também na dinâmica das manifestações. Isso porque há grande dificuldade em tipificar as práticas das facções criminosas como atos terroristas sem provocar, indiretamente, sufocamento democrático - a proposta do Senador Magno Malta, de qualificar como terroristas atos com "motivação política, ideológica ou social" é simbólica dessa inevitável confusão.

A problematização central do artigo é que movimentos sociais, manifestações e coletivos, entre outras formas de organização social, atribuem significados importantes às lutas sociais, fortalecendo a democracia como um sistema participativo, sobretudo em um país marcado por inúmeras desigualdades sociais - quando marcadores de raça, classe e gênero são tidos como fundamentais no acesso à cidadania. A reunião de pessoas, a institucionalização de grupos, a abertura de espaços de discussão e debate são mecanismos de enfrentamento e negociação com o Estado, aspectos centrais em uma democracia participativa. Portanto a democracia não é algo dado e acabado - está em permanente construção, muitas vezes movida por protestos e exigências por melhores formas de sobrevivência que devem, portanto, ser legitimadas pelo Estado, em vez de criminalizadas.

Em suma, qualquer proposta de alteração à Lei no 13.260/2016 deve ser analisada com cautela, a fim de prevenir reflexos democraticamente indesejáveis. Isso, especialmente, no que se refere ao Projeto de Lei do Senado no 272/2016, pois a modificação proposta tem o potencial de acarretar gravíssimos prejuízos à manutenção e ao desenvolvimento da democracia brasileira.

Danielle Maia Cruz é pós-doutora em Avaliação de Políticas Públicas pelo Programa de PósGraduação em Avaliação de Políticas Públicas da Universidade Federal do Ceará, Doutora em Sociologia e professora da Universidade de Fortaleza e do Programa de Pós-Graduação em Avaliação de Políticas Públicas da Universidade Federal do Ceará.

$\triangle$ dmaiacruz7@gmail.com

Fábio Carvalho de Alvarenga Peixoto é Mestre em Direito e Gestão de Conflitos e doutorando em Direito Constitucional na Universidade de Fortaleza.

$\bowtie$ fabiocapeixoto@gmail.com 


\section{Referências}

1. ALAGOAS. Lei no 7.692, de 8 de abril de 2015. Estabelece a proibição, em reuniões públicas para manifestações de pensamento, do uso de máscara ou qualquer outra forma que vise ocultar o rosto do cidadão, com o propósito de impedir-lhe a identificação. Diário Oficial do Estado de Alagoas, ano 103, n. 69, p. 1, 14 de abril de 2015 .

2. ALKHUDARY, Taif. Five years on, still no justice for Iraq's Camp Speicher victims. Al Jazeera, Doha, 12 jun. 2019. Disponível em: https://www.aljazeera.com/ indepth/opinion/years-justice-iraq-camp-speicher-victims-190612085910106.html

3. AMAZONAS. Lei no 3.993, de 15 de janeiro de 2014. Regulamenta o direito à reunião pública para manifestação de pensamento, no âmbito do estado do Amazonas, e dá outras providências. Diário Oficial do Estado do Amazonas, n. 32721, p. 6, 15 janeiro de 2014.

4. ARQUIDIOCESE DE SÃO PAULO. Brasil: nunca mais. 32. ed. Petrópolis: Vozes, 2001.

5. AVELAR, Daniel. Leis antiterrorismo são usadas para reprimir o dissenso em outros países; veja exemplos. Mundialíssimo, São Paulo, 7 dez. 2018. Disponível em: https://mundialissimo.blogfolha.uol.com.br/2018/12/07/leisantiterrorismo-sao-usadas-para-reprimir-o-dissenso-em-outros-paises/

6. BOLSONARO, Jair M. Ao criminoso não interessa o partido desse ou daquele governador [...]. Brasília, 12 jan. 2019. Twitter: @jairbolsonaro. Disponível em: https://twitter.com/jairbolsonaro/status/1083997855600267264

7. BORGES, Messias. Recorde de homicídios e onda de ataques levaram Ceará a ampliar controle em presídios e integrar forças de segurança. G1, Rio de Janeiro, 2 jun. 2019. Disponível em: https://g1.globo.com/ce/ceara/noticia/2019/06/02/ recorde-de-homicidios-e-onda-de-ataques-levaram-ceara-a-ampliar-controleem-presidios-e-integrar-forcas-de-seguranca.ghtml

8. BRASIL. Lei no 13.260, de 16 de março de 2016. Regulamenta o disposto no inciso XLIII do art. $5^{\circ}$ da Constituição Federal, disciplinando o terrorismo, tratando de disposições investigatórias e processuais e reformulando o conceito de organização terrorista; e altera as Leis nos 7.960, de 21 de dezembro de 1989, e 12.850, de 2 de agosto de 2013. Diário Oficial da União, n. 52-A, seção 1, p. 1, 17 mar. 2016a. Disponível em: http://www.planalto.gov.br/ccivil 03/Ato20152018/2016/Lei/L13260.htm

9. BRASIL. Mensagem no 85, de 16 de março de 2016. Diário Oficial da União, n. 52-A, seção 1, p. 5, 17 mar. 2016b. Disponível em: http://www.planalto.gov.br/ ccivil_03/_ato2015-2018/2016/Msg/VEP-85.htm

10. BRASIL. Decreto no 5.639, de 26 de dezembro de 2005. Promulga a Convenção Interamericana contra o terrorismo, assinada em Barbados, em 3 de junho de 2002. Diário Oficial da União, n. 248, seção 1, p. 12, 27 dez. 2005. Disponível em: http://www.planalto.gov.br/ccivil_03/_Ato2004-2006/2005/Decreto/D5639.htm 
11. BRASIL. Lei $\mathrm{n}$ - 7.170, de 14 de dezembro de 1983. Define os crimes contra a segurança nacional, a ordem política e social, estabelece seu processo e julgamento e dá outras providências. Diário Oficial da União, seção 1, p. 21004, 15 dez. 1983. Disponível em: http://www.planalto.gov.br/ccivil 03/leis/l7170.htm

12. BRASIL. Lei no 6.683, de 28 de agosto de 1979. Concede anistia e dá outras providências. Diário Oficial da União, p. 12265, 28 ago. 1979. Disponível em: http://www.planalto.gov.br/ccivil_03/leis/L6683.htm

13. BRASIL. Senado Federal. Projeto de Lei do Senado no 272, de 2016. Altera a Lei no 13.260, de 16 de março de 2016, a fim de disciplinar com mais precisão condutas consideradas como atos de terrorismo. Brasília, DF: Senado Federal, 2016c. Disponível em: https://legis.senado.leg.br/sdleg-getter/ documento $\mathrm{dm}=4053697 \&$ ts $=1548431814222 \&$ disposition=inline

14. BRASIL. Senado Federal. Parecer [do Sen. Magno Malta]. Da Comissão de Constituição, Justiça e Cidadania, em decisão terminativa, sobre o Projeto de Lei do Senado (PLS) no 272, de 2016, do Senador Lasier Martins, que altera a Lei no 13.260, de 16 de março de 2016, a fim de disciplinar com mais precisão condutas consideradas como atos de terrorismo. Brasília, DF: Senado Federal, 2018. Disponível em: https://legis.senado.leg.br/sdleg-getter/ documento $\mathrm{dm}=7649144 \&$ ts $=1548953807010 \&$ disposition=inline

15. BRASIL. Senado Federal. Voto em separado [do Sen. Randolfe Rodrigues]. Perante a Comissão de Constituição, Justiça e Cidadania, em decisão terminativa, sobre o Projeto de Lei do Senado n. 272 , de 2016, do Senador Lasier Martins, que altera a Lei n. $\underline{\text { 13.260, de }} 16$ de março de 2016, a fim de disciplinar com mais precisão condutas consideradas como atos de terrorismo. Brasília, DF: Senador Federal, 2016d. Disponível em: https://legis.senado.leg.br/sdleg-getter/ documento $\mathrm{dm}=7728732 \& \mathrm{ts}=1548431814509 \&$ disposition=inline

16. BRASIL. Supremo Tribunal Federal (Tribunal Pleno). Ext. no 855. Extradição - Atos delituosos de natureza terrorista - Descaracterização do terrorismo como prática de criminalidade política [...]. Requerente: Governo Chile. Extraditando: Maurício Hernandez Clavery Guido e outros. Relator: Min. Celso de Mello, 26 ago. 2004. Diário da Justiça, 1 jul. 2005. Disponível em: http://redir.stf.jus.br/ paginadorpub/paginador.jsp?docTP $=$ AC\&docID $=325004$

17. BRASIL. Supremo Tribunal Federal (Tribunal Pleno). Ext. no 493. Extradição. Argentina. Invasão do Quartel de La Tablada. Criminalidade Política. Denegação. [...]. Requerente: Governo da República Argentina. Extraditando: Fernando Carlos Falco. Relator: Min. Sepúlveda Pertence, 4 out. 1989. Diário da Justiça, Poder Judiciário, Brasília, DF, 3 ago. 1990. Disponível em: http://redir.stf.jus.br/ paginadorpub/paginador.jsp?docTP $=\mathrm{AC} \&$ docID $=324725$

18. CAMBI, Eduardo A. S.; AMBROSIO, Felipe A. R. Lei antiterror brasileira (Lei no 13.260/16): ameaça à democracia e aos direitos fundamentais. Questio luris, v. 10, n. 3, p. 1370-1397, 2017.

19. CASTILHO, Natalia M.; FEITOSA, Gustavo R. P. Direito a resistir ao direito? A atuação judicial no caso da ocupação Raízes da Praia em contextos de violação aos direitos fundamentais. Pensar - Revista de Ciências Jurídicas, v. 23, p. 10121030, 2016. 
20. CEARÁ. Lei no 15.984, de 16 de março de 2016. Dispõe sobre a proibição às empresas de serviço de telefonia móvel de concessão de sinais de rádio comunicação em áreas destinadas às unidades prisionais do estado do Ceará. Diário Oficial do Estado, série 3, ano VIII, n. 053, p. 1, 18 de março de 2016. Disponível em: http:// imagens.seplag.ce.gov.br/PDF/20160318/do20160318p01.pdf

21. CERTEAU, Michel de. A invenção do cotidiano: artes de fazer. Petrópolis: Vozes, 1994. (v. 1).

22. CHRISAFIS, Angelique; FISCHER, Sofia; RICE-OXLEY, Mark. France stunned after truck attacker kills 84 on Bastille Day in Nice. The Guardian, Londres, 15 jul. 2016. Disponível em: https://www.theguardian.com/world/2016/jul/15/niceattack-leaves-84-dead-and-france-in-shock

23. COELHO, Marcelo. O imaginário da crise. In: NOVAES, Adauto (org.). Civilização e barbárie. São Paulo: Companhia das Letras, 2004. p. 125-148.

24. COSTA, Frederico C. de S. Terrorismo, racionalidade e democracia. Centro de Pesquisas Estratégicas "Paulino Soares de Sousa", Universidade Federal de Juiz de Fora, 16 jan. 2006.

25. DICHTCHEKENIAN, Patrícia. Projeto de lei antiterrorismo na Câmara ameaça direito de protesto e movimentos sociais. Operamundi, São Paulo, 11 ago. 2015. Disponível em: https://operamundi.uol.com.br/politica-e-economia/41295/projetode-lei-antiterrorismo-na-camara-ameaca-direito-de-protesto-e-movimentos-sociais

26. DIÓGENES, Glória. Cartografias da cultura e da violência: gangues, galeras e movimento hip-hop. São Paulo: Annablume, 2008.

27. ENTENDA o que é o ativismo "Black Bloc" presente nas manifestações. Folha de São Paulo, São Paulo, 11 jul. 2013. Disponível em: https://www1.folha.uol. com.br/cotidiano/2013/07/1309858-entenda-o-que-e-o-ativismo-black-blocpresente-nas-manifestacoes.shtml

28. FESSY, Thomas. Boko Haram: o que aconteceu em Baga? BBC News Brasil, Londres, 3 fev. 2015. Disponível em: https://www.bbc.com/portuguese/ noticias/2015/02/150203_nigeria_baga_lk

29. FORTALEZA. Desenvolvimento humano, por bairro, em Fortaleza. Fortaleza: Prefeitura de Fortaleza, Secretaria Municipal de Desenvolvimento Econômico, 2014. Disponível em: http://salasituacional.fortaleza.ce.gov.br:8081/ acervo/documentByld?id=22ef6ea5-8cd2-4f96-ad3c-8e0fd2c39c98

30. FORTE, Gustavo N. A olimpíada passará e a lei antiterrorismo fica. Folha de São Paulo, São Paulo, 21 mar. 2016. Disponível em: https://www1.folha.uol.com. br/poder/2016/03/1752500-a-olimpiada-passara-e-a-lei-antiterrorismo-fica.shtml

31. GOHN, Maria da G. Movimentos sociais e movimentos coletivos em São Paulo: o papel da política, dos mediadores e da media nas mobilizações, manifestações e protestos nas ruas na atualidade. In: ENCONTRO DA ASSOČIAÇÃO BRASILEEIRA DE CIÊNCIA POLÍTICA, 10., 2016, Belo Horizonte. Anais... Belo Horizonte, 2016. p. 1-19. 
32. GOMEZ TORRES, Carmelo J. El abuso de los derechos fundamentales. In: PÉREZ LUÑO, Antonio Enrique (coord.). Los derechos humanos: significación, estatuto jurídico y sistema. Sevilha: Universidad de Sevilla, 1979. p. 301-332.

33. GUEDES, Sylvio. Manifestações ficam fora de projeto de lei antiterror. Revista em Discussão [Senado Federal], Brasília, DF, ano 5, n. 20, p. 50-51, abr. 2014.

34. HARTMANN, Christian. Bataclan é palco de maior ataque em noite de terror em Paris. Gazeta do Povo, Curitiba, 13 nov. 2015. Disponível em: https://www. gazetadopovo.com.br/mundo/bataclan-e-palco-de-maior-ataque-em-noite-deterror-em-paris-8t13qfwml16s4mthzh0d6hpny/

35. HESSEL, Stéphane. Indignai-vos! Lisboa: Ed. Objectiva, 2011.

36. HIRATA, Daniel V.; GRILLO, Carolina C. Sintonia e amizade entre patrões e donos de morro: perspectivas comparativas entre o comércio varejista de drogas em São Paulo e no Rio de Janeiro. Tempo social, v. 29, n. 2, p. 75-97, 2017.

37. HOBSBAWM, Eric. Globalização, democracia e terrorismo. São Paulo: Companhia das Letras, 2007.

38. KRYGIER, Martin. The rule of law: an abuser's guide. University of New South Wales Law Research Paper, Sydney, n. 2007-4, 2007. http://dx.doi.org/10.2139/ ssrn.952576

39. LEBON, G. The crowd. Nova York: Viking, 1985.

40. LEITE, Márcia P. Entre o individualismo e a solidariedade: dilemas da política e da cidadania no Rio de Janeiro. Revista Brasileira de Ciências Sociais, v. 15, n. 44, p. 43-90, 2000.

41. LOPES, Ana Maria d'Á.; SANTOS JR., Luís Haroldo P. "Conflito mapuche": aplicação da lei antiterrorista e violação de direitos humanos. Revista Direito

\& Práxis, v. 9, n. 2, p. 587-609, 2018. https://doi.org/10.1590/2179$\underline{8966 / 2017 / 26897}$

42. MARQUES, Camila; RIELLI, Mariana. PL antiterrorismo é ameaça a movimentos sociais e manifestantes. Consultor Jurídico, São Paulo, 15 mar. 2016. Disponível em: https://www.conjur.com.br/2016-mar-15/pl-antiterrorismoameaca-movimentos-sociais-manifestantes

43. MASSACRE do Boko Haram teve pouca repercussão internacional; entenda. G1, Rio de Janeiro, 13 jan. 2015. Disponível em: http://g1.globo.com/ mundo/noticia/2015/01/massacre-do-boko-haram-teve-pouca-repercussaointernacional-entenda.html

44. MATO GROSSO. Lei no 10.191, de 26 de novembro de 2014. Dá efetividade ao exercício do direito de reunião e manifestação pública. Diário Oficial do Estado de Mato Grosso, n. 26424, p. 3, 26 de novembro de 2014. Disponível em: https://www.iomat.mt.gov.br/portal/visualizacoes/pdf/3852\#/p:3/ e:3852?find $=\mid e i \% 2010191$ 
45. MELO, Ranniery. Atos criminosos no Ceará "precisam ser tipificados como terrorismo", diz o governador Camilo Santana. G1, Rio de Janeiro, 17 jan. 2019. Disponível em: https://g1.globo.com/ce/ceara/noticia/2019/01/17/ atos-criminosos-no-ceara-precisam-ser-tipificados-como-terrorismo-diz-ogovernador-camilo-santana.ghtml

46. MINAS GERAIS. Lei no 21.324, de 17 de junho de 2014. Restringe o uso de máscara, venda ou qualquer cobertura que oculte a face em eventos multitudinários. Minas Gerais, Diário Oficial dos Poderes do Estado, Caderno 1 - Diário do Executivo, n. 122, p. 1, 18 de junho de 2014. Disponível em: http:// jornal.iof.mg.gov.br/xmlui/handle/123456789/124113

47. MUNHOZ, Laertes M. Repressão internacional da criminalidade. Revista da Faculdade de Direito UFPR, Curitiba, v. 1, p. 121-146, 1953. Disponível em: https://revistas.ufpr.br/direito/article/download/6159/4395

48. NAÇÕES UNIDAS. Relatores da ONU alertam que lei antiterrorismo é "muito ampla" e pode restringir direitos. ONU News, 4 nov. 2015. Disponível em: https://news.un.org/pt/story/2015/11/1530701-relatores-da-onu-alertam-leiantiterrorismo-do-brasil-e-muito-ampla

49. NICARÁGUA. Ley no 977, aprobado el $\mathbf{1 6}$ de julio del 2018. Ley contra el lavado de activos, el financiamiento al terrorismo y el financiamiento a la proliferación de armas de destrucción masiva. Manágua: Asamblea Nacional, 2018. Disponível em: https://www.uaf.gob.ni/images/Pdf/Leyes/Ley N. 977 Ley Contra el LA-FT-FPADM.PDF

50. NOSSITER, Adam. Satellite images show ruin left by Boko Haram, groups say. The New York Times, 15 jan. 2015. Disponível em: https://www.nytimes. com/2015/01/16/world/africa/boko-haram-rampage-in-nigeria-is-shown-insatellite-images-groups-say.html

51. OLIVEIRA, Marcelo A. C. Comentário ao artigo 1으, parágrafo único. In: CANOTILHO, J. J. Gomes et al. (coords.). Comentários à Constituição do Brasil. São Paulo: Saraiva; Porto: Almedina, 2013. E-book.

52. ONU denuncia lei da Nicarágua que pode criminalizar protestos. Exame, São Paulo, 17 jul. 2018. Disponível em: https://exame.abril.com.br/mundo/onudenuncia-lei-da-nicaragua-que-pode-criminalizar-protestos/

53. PAIVA, Luiz Fábio S. "AQUI NÃO TEM GANGUE, TEM FACÇÃO": as transformações sociais do crime em Fortaleza, Brasil. Cad. CRH, v. 32, n. 85, p. 165-184, 2019. https://doi.org/10.9771/ccrh.v32i85.26375

54. PAPE, Robert. The strategic logic of suicidal terrorism. American Political Science Review, v. 97, n. 3, p. 343-361, ago. 2003. https://doi.org/10.1017/ $\underline{\text { S000305540300073X }}$

55. PEIXOTO, Fábio C. de A. Manifestação em via pública: o direito de reunião na rua. Rio de Janeiro: Lumen Juris, 2019.

56. PETRIKOWSKI, Nicki P. Charlie Hebdo shooting. Encyclopedia Britannica, Londres, 13 fev. 2019. Disponível em: https://www.britannica.com/event/CharlieHebdo-shooting 
57. PORTO ALEGRE. Lei no 11.596, de 2 de abril de 2014. Pró́be os cidadãos de utilizarem máscara ou qualquer meio capaz de ocultar o rosto com o propósito de impedir sua identificação em manifestações públicas no município de Porto Alegre e normatiza o direito constitucional dos cidadãos à participação em reuniões públicas. Diário Oficial do Município, n. 4729, p. 1, 3 de abril de 2014. Disponível em: http://dopaonlineupload.procempa.com.br/ dopaonlineupload/1089 ce 91762 1.pdf

58. PORTUGAL. Lei no 52, de 22 de agosto de 2003. Lei de combate ao terrorismo (em cumprimento da Decisão Quadro no 2002/475/JAI, do Conselho, de 13 de Junho) - décima segunda alteração ao Código de Processo Penal e décima quarta

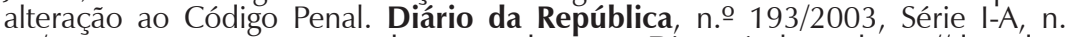
52/2003, p. 5398-5400, 22 de agosto de 2003. Disponível em: https://data.dre. pt/eli/lei/52/2003/08/22/p/dre/pt/html

59. PRADO, Luiz R.; CARVALHO, Érika M. Delito político e terrorismo: uma aproximação conceitual. Revista dos Tribunais, v. 771, p. 421-447, 2000. Disponível em: https://dspace.almg.gov.br/handle/11037/37615

60. PNUD - Programa das Nações Unidas para o Desenvolvimento. Relatório do desenvolvimento humano 2019: além do rendimento, além das médias, além do presente: desigualdades no desenvolvimento humano no século XXI. Nova lorque: PNUD, 2019. Disponível em: http://hdr.undp.org/sites/default/files/ hdr 2019 pt.pdf

61. RENNER, Mauro H.; RENNER, Olavo G. Terrorismo e direitos fundamentais: uma pauta necessária. In: Seminário Internacional de Demandas Sociais e Políticas Públicas na Sociedade Contemporânea, 13., 2016, Santa Cruz do Sul. Anais... Santa Cruz do Sul, 2016. p. 1-19. Disponível em: https://online.unisc.br/acadnet/ anais/index.php/sidspp/article/view/15766

62. RIO DE JANEIRO (Estado). Lei no 6.528, de 11 de setembro de 2013. Regulamenta o artigo 23 da Constituição do Estado. Diário Oficial do Estado do Rio de Janeiro, Parte I, Poder Executivo, n. 170, p. 1, 12 de setembro de 2013. Disponível em: https://rb.gy/yque7i

63. SAINT-PIERRE, Héctor L. 11 de Setembro: do terror à injustificada arbitrariedade e o terrorismo de Estado. Revista de Sociologia e Política, v. 23, n. 53, p. 9-26, 2015. https://doi.org/10.1590/1678-987315235302

64. SANTOS, Boaventura de S. Renovar a teoria crítica e reinventar a emancipação social. São Paulo: Boitempo, 2007.

65. SANTOS, Boaventura de S.; AVRITZER, Leonardo. Introdução: para ampliar o cânone democrático. In: SANTOS, Boaventura de S. (org.). Democratizar a democracia: os caminhos da democracia participativa. Rio de Janeiro: Civilização Brasileira, 2002. p. 39-82.

66. SÃO PAULO (Estado). Lei no 15.552, de 29 de agosto de 2014. Restringe o uso de máscaras ou qualquer paramento que oculte o rosto da pessoa em manifestações e reuniões, na forma que especifica, e dá providências correlatas. Diário Oficial do Estado de São Paulo, v. 124, n. 163, p. 1, 30 de agosto de 2014. Disponível em: https://www.al.sp.gov.br/repositorio/legislacao/lei/2014/lei15556-29.08.2014.html 
67. SARLET, Ingo W.; WEINGARTNER NETO, Jayme. Democracia desmascarada? Liberdade de reunião e manifestação: uma resposta constitucional contrahegemônica. In: CLÈVE, Clèmerson M.; FREIRE, Alexandre. Direitos fundamentais e jurisdição constitucional. São Paulo: Revista dos Tribunais, 2014. p. 477-496.

68. SEIXAS, Eunice C. "Terrorismos": uma exploração conceitual. Revista de Sociologia e Política, v. 16, número suplementar, p. 9-26, 2008.

69. SOARES, Denise de S. De Marx a Deus: os tortuosos caminhos do terrorismo internacional. Rio de Janeiro: Renovar, 2003.

70. SOUSA, Devilson da R.; GORCZEVSKI, Clóvis. A lei antiterrorismo brasileira e o retrocesso aos direitos humanos: um campo aberto para violações e autoritarismo. Revista Húmus, São Luís, v. 8, n. 24, p. 49-63, 2018.

71. SOUZA, Felipe. Ceará sob ataque: como facções locais e nacionais se juntaram para dominar o crime no estado. BBC Brasil, Londres, 8 jan. 2019. Disponível em: https://www.bbc.com/portuguese/brasil-46789403

72. TILLY, Charles. From mobilization to revolution. Nova York: Newbery Award Records, 1978.

73. WEBER, Max. Economia e sociedade: fundamentos da sociologia compreensiva. Brasília, DF: Universidade de Brasília, 2014.

Recebido em: 27 set. 2019.

Aceito em: 21 jul. 2020. 
